\title{
A Unique Relative of Rotifer Birnavirus Isolated from Australian Mosquitoes
}

\author{
Caitlin A. O’Brien ${ }^{1,2}{ }^{-1}$, Cassandra L. Pegg ${ }^{2}$, Amanda S. Nouwens ${ }^{2}$, Helle Bielefeldt-Ohmann ${ }^{1,2}$, \\ Bixing Huang ${ }^{3}$, David Warrilow ${ }^{3}{ }^{-}$, Jessica J. Harrison ${ }^{1,2}$, John Haniotis ${ }^{4}$, \\ Benjamin L. Schulz ${ }^{1,2}{ }^{\circledR}$, Devina Paramitha ${ }^{1,2}$, Agathe M. G. Colmant ${ }^{1,2}$, Natalee D. Newton ${ }^{1,2}$, \\ Stephen L. Doggett ${ }^{4}\left(\mathbb{D}\right.$, Daniel Watterson ${ }^{1,2}$, Jody Hobson-Peters ${ }^{1,2}{ }^{-}$and Roy A. Hall 1,2,* \\ 1 Australian Infectious Diseases Research Centre, School of Chemistry and Molecular Biosciences, \\ The University of Queensland, Brisbane, QLD 4067, Australia; caitlin.obrien@uqconnect.edu.au (C.A.O.); \\ h.bielefeldtohmann1@uq.edu.au (H.B.-O.); jessica.harrison@uqconnect.edu.au (J.J.H.); \\ b.schulz@uq.edu.au (B.L.S.); devina.paramitha@uq.net.au (D.P.); agathe.colmant@uq.net.au (A.M.G.C.); \\ natalee.newton@uq.net.au (N.D.N.); d.watterson@uq.edu.au (D.W.); j.peters2@uq.edu.au (J.H.-P.) \\ 2 School of Chemistry and Molecular Biosciences, The University of Queensland, \\ Brisbane, QLD 4067, Australia; c.pegg1@uq.edu.au (C.L.P.); a.nouwens@uq.edu.au (A.S.N.) \\ 3 Public Health Virology, Queensland Health Forensic and Scientific Services, Brisbane, QLD 4108, Australia; \\ Ben.Huang@health.qld.gov.au (B.H.); David.Warrilow@health.qld.gov.au (D.W.) \\ 4 New South Wales Health Pathology, Westmead Hospital, Sydney, NSW 2145, Australia; \\ John.Haniotis@health.nsw.gov.au (J.H.); Stephen.Doggett@health.nsw.gov.au (S.L.D.) \\ * Correspondence: roy.hall@uq.edu.au
}

Received: 23 August 2020; Accepted: 17 September 2020; Published: 22 September 2020

\begin{abstract}
The family Birnaviridae are a group of non-enveloped double-stranded RNA viruses which infect poultry, aquatic animals and insects. This family includes agriculturally important pathogens of poultry and fish. Recently, next-generation sequencing technologies have identified closely related birnaviruses in Culex, Aedes and Anopheles mosquitoes. Using a broad-spectrum system based on detection of long double-stranded RNA, we have discovered and isolated a birnavirus from Aedes notoscriptus mosquitoes collected in northern New South Wales, Australia. Phylogenetic analysis of Aedes birnavirus (ABV) showed that it is related to Rotifer birnavirus, a pathogen of microscopic aquatic animals. In vitro cell infection assays revealed that while ABV can replicate in Aedes-derived cell lines, the virus does not replicate in vertebrate cells and displays only limited replication in Culex- and Anopheles-derived cells. A combination of SDS-PAGE and mass spectrometry analysis suggested that the ABV capsid precursor protein (pVP2) is larger than that of other birnaviruses and is partially resistant to trypsin digestion. Reactivity patterns of ABV-specific polyclonal and monoclonal antibodies indicate that the neutralizing epitopes of ABV are SDS sensitive. Our characterization shows that ABV displays a number of properties making it a unique member of the Birnaviridae and represents the first birnavirus to be isolated from Australian mosquitoes.
\end{abstract}

Keywords: birnavirus; mosquitoes; insect-specific virus; Aedes birnavirus; Aedes notosrciptus

\section{Introduction}

The family Birnaviridae comprises a group of non-enveloped viruses with bi-segmented, double-stranded RNA (dsRNA) genomes. Birnaviruses are unique among dsRNA viruses as they appear to share structural and phylogenetic characteristics with positive-sense single-stranded RNA ( + ssRNA) viruses [1,2].

To date, four genera have been established based on virus host range-Avibirnavirus, which contains only the type species infectious bursal disease virus (IBDV); Blosnavirus, containing blotched snakehead 
virus (BSNV); Aquabirnavirus, encompassing infectious pancreatic necrosis virus (IPNV) and its relatives; and Entomobirnavirus, comprising type species Drosophila X virus (DXV) and related viruses from insects [3]. A number of divergent viruses remain unassigned to any genus within the family including Rotifer birnavirus (RBV), a pathogen of the rotifer Branchionus plicatilis [4] and Drosophila birnavirus (DBV) which was identified in small RNA sequencing from Drosophila melanogaster, but does not phylogenetically group with the entomobirnaviruses [5].

The birnavirus genome is made up of two segments. Segment A encodes a polyprotein which contains the capsid protein precursor pVP2, endopeptidase VP4 and ribonucleoprotein VP3. VP4 is responsible for autoproteolytic processing of the polypeptide to release the three individual proteins. In some birnaviruses, a second open reading frame on this segment gives rise to a small non-structural protein [6]. Segment B encodes VP1, the viral RNA-dependent RNA polymerase (RdRP) which possesses an unusual A-B-C to C-A-B catalytic motif rearrangement and lacks the characteristic GDD motif found in other viral RdRPs [2,7-9].

Birnavirus replication occurs in the cytoplasm of infected cells and the immature birnavirus particle is formed by the association of pVP2 with VP3, in complex with the viral genome and VP1 [10-15]. Virus maturation occurs via a succession of cleavage events at the C-terminus of $\mathrm{pVP} 2$, leading to production of icosahedral particles primarily consisting of the mature form of VP2 in a $\mathrm{T}=13$ symmetry $[6,12,15]$. The resulting $\mathrm{pVP} 2$ cleavage products remain associated with the mature virion [6].

In 2011, the isolation of a new birnavirus which exhibited enhanced replication in the presence of a virulent strain of dengue-2 virus was reported [16]. The origin of this virus, named Espirito Santo virus (ESV), was unclear but its relatedness to DXV and inability to replicate in vertebrate cells suggested that it was a member of the Entomobirnavirus genus. Mosquito X virus (MXV) and Culex $\mathrm{Y}$ virus (CYV), which share high genetic similarity to ESV, have since been identified in wild-caught Culex pipiens and Anopheles sinensis mosquitoes in the absence of dengue virus [17,18]. The related Culicine-associated $\mathrm{Z}$ virus (CAZV) was identified from metagenomic sequencing data of Aedes (Ochlerotatus) caspius and Ae. (Oc.) detritus mosquitos from France [19]. Most recently, the isolation of Port Bolivar virus (PTBV) from Ae. sollicitans mosquitoes in America was reported [20]. Phylogenetic analyses suggest that ESV and the mosquito-associated birnaviruses form a subclade, separate from the Drosophila-associated viruses within the Entomobirnavirus genus $[3,19,20]$.

The advent of next-generation sequencing technologies has shed light on a previously overlooked group of viruses in diptera, the insect-specific viruses (ISVs) [21]. As their name suggests, these viruses lack the ability to replicate in vertebrate systems but are maintained in insect populations, presumably via a variety of mechanisms including vertical, and oral-fecal route transmission [21]. ISVs have become the focus of increasing research due to their potential as biological control mechanisms, safe vehicles for vaccine delivery, and their contribution to elucidating viral evolution and virus-host interactions [22-25]. We have undertaken a virus discovery project in order to broaden our understanding of the virome of Australian mosquitoes, using a broad-spectrum, high-throughput ELISA-based method. This method, the monoclonal antibodies to viral RNA intermediates in cells (MAVRIC) system, utilizes two antibodies which recognize long ( $>30 \mathrm{bp}$ ) dsRNA molecules, a common component of RNA virus replication, in a sequence-independent manner [26] and has been highly successful [25,27-33]. Here, we report the discovery of a birnavirus from Australian mosquitoes using this system. This virus is phylogenetically distinct from the Entomobirnavirus genus and its growth is restricted to Aedes-derived cell culture systems.

\section{Materials and Methods}

\subsection{Mosquito Collection, Processing and Virus Culture}

Mosquitoes were collected in dry ice-baited traps at various sites in New South Wales (NSW), Australia, between March and April in 2013 and 2014 as part of routine arbovirus surveillance in the region. Individual mosquitoes were identified using morphological criteria [29] and pooled into 
groups of up to 25 insects. Pools were mechanically homogenized in cell culture media with glass beads and passed through a $0.2 \mu \mathrm{m}$ filter before inoculating onto Aedes albopictus larval (C6/36) cells. Methods for mosquito collection from Western Australia and Darwin have been described previously [29,34].

For MAVRIC screening, C6/36 cells were seeded at 50-70\% confluence in 96-well plates one day prior to inoculation and incubated at $28{ }^{\circ} \mathrm{C}$. The following day, $50 \mu \mathrm{L} /$ well of mosquito homogenate was added to four replicate wells for each mosquito pool. West Nile virus subtype kunjin was used as a positive control for dsRNA production and cells inoculated with media alone (mock infection) served as a negative control. After 7 days, supernatant was harvested from inoculated wells and plates were fixed with $150 \mu \mathrm{L} /$ well formaldehyde fixative buffer ( $4 \%$ formaldehyde, $0.5 \% v / v$ Triton X-100 in phosphate-buffered saline (PBS; $140 \mathrm{mM} \mathrm{NaCl}, 2.7 \mathrm{mM} \mathrm{KCl}, 6 \mathrm{mM} \mathrm{Na}_{2} \mathrm{HPO}_{4}, 0.9 \mathrm{mM} \mathrm{KH}_{2} \mathrm{PO}_{4}$ ) for 10 min at $4{ }^{\circ} \mathrm{C}$. After removing fixative, plates were allowed to dry for at least two days before fixed-cell ELISA was performed.

Plates were incubated with $150 \mu \mathrm{L} /$ well TENTC blocking buffer ( $2 \% w / v$ casein, $0.05 \% v / v$ Tween-20, $10 \mathrm{mM}$ Tris, $0.2 \mathrm{M} \mathrm{NaCl}, 1 \mathrm{mM}$ EDTA, $\mathrm{pH}$ 8.0) for $1 \mathrm{~h}$ at room temperature. A cocktail of anti-dsRNA monoclonal antibodies (mAbs) 3G1 and 2G4 (MAVRIC) was freshly prepared by diluting hybridoma supernatant to a previously determined optimal concentration in TENTC blocking buffer. After removing blocking solution, $50 \mu \mathrm{L}$ of MAVRIC cocktail was added to each well and plates were incubated at $37^{\circ} \mathrm{C}$ for $1 \mathrm{~h}$. Plates were washed four times with phosphate-buffered saline with $0.05 \% v / v$ Tween-20 (PBS-T) and goat anti-mouse HRP (DAKO) diluted in TENTC blocking buffer was added at $50 \mu \mathrm{L} /$ well. After another incubation at $37{ }^{\circ} \mathrm{C}$ for $1 \mathrm{~h}$, plates were washed 6 times with PBS-T. Finally, plates were incubated with $100 \mu \mathrm{L} /$ well of substrate buffer $(1 \mathrm{mM}$ 2,2'-Azino-bis(3-ethylbenzothiazoline-6-sulfonic acid) (ABTS), $2.5 \mathrm{mM} \mathrm{H}_{2} \mathrm{O}_{2}$, in a solution prepared by mixing $0.1 \mathrm{M}$ citric acid with $0.2 \mathrm{M} \mathrm{Na}_{2} \mathrm{HPO}_{4}$ to give a $\left.\mathrm{pH} 4.2\right)$ for $1 \mathrm{~h}$ at room temperature, protected from light. Absorbance was measured at $405 \mathrm{~nm}$ and samples with an average $\mathrm{OD}_{405 \mathrm{~nm}}$ equal to or greater than twice that of the average mock reading were considered positive. MAVRIC-positive samples were tested for the presence of LNV by fixed-cell ELISAs using anti-LNV mAb 6E6 with the method described above [28].

Aedes birnavirus (ABV) was isolated from two pools of 25 Ae. notoscriptus mosquitoes (pool numbers 177833 and 178287) collected in Ballina, NSW in 2013. Mosquito homogenates, which were identified as MAVRIC positive, were inoculated onto C6/36 cells and cultured for 7 days at $28^{\circ} \mathrm{C}$. These samples were passaged twice in 96-well plates before upscaling to a 24 well plate for the 3 rd passage.

MAVRIC-positive samples were tested for the presence of known mosquito-borne viruses by RT-PCR with the primers listed in Table S1. Briefly, RNA was extracted from supernatants of MAVRIC-positive cultures using the Machery-Nagel Nucleospin viral RNA isolation kit as per the manufacturer's instructions. One-step RT-PCR was performed on extracted RNA using the ThermoFisher Superscript III one-step RT-PCR kit. The following cycling conditions were used for all primer sets: reverse transcription: $45^{\circ} \mathrm{C} / 30 \mathrm{~min}$; PCR: one cycle $94{ }^{\circ} \mathrm{C} / 2 \mathrm{~min} ; 40$ cycles $94{ }^{\circ} \mathrm{C} / 30 \mathrm{~s}$, $45^{\circ} \mathrm{C} / 30 \mathrm{~s}, 68^{\circ} \mathrm{C} / 1 \mathrm{~min}$; followed by a final extension cycle of $68^{\circ} \mathrm{C} / 5 \mathrm{~min}$.

\subsection{Next Gneration Sequencing and Bioinformatic Analyses}

A confluent T175 flask of C6/36 cells was inoculated with $200 \mu \mathrm{L}$ of supernatant from a passage 3 stock of isolate 177833 and incubated for 7 days at $28^{\circ} \mathrm{C}$. Harvested supernatant was clarified by centrifugation at $3000 \mathrm{rpm}$ for $15 \mathrm{~min}$ at $4{ }^{\circ} \mathrm{C}$.

RNA was extracted from the clarified supernatant using the QIAamp Viral RNA extraction kit (Qiagen, Hilden, Germany) with carrier RNA omitted. Residual cell line DNA was removed using DNA Wipeout (Qiagen). First-strand cDNA synthesis was generated using the Protoscript II kit using the supplied random primer mix (New England Biolabs; Ipswich, MA, USA). Second-strand DNA synthesis was performed using the NEBNext mRNA Second-Strand Synthesis Module (New England Biolabs). cDNA libraries were constructed using the Nextera XT library kit (Illumina; Singapore, Singapore) with barcoding of individual samples. These reactions were performed according to 
the conditions recommended by the respective manufacturers. Library sequencing was performed by the Australian Genome Research Facility (AGRF) on a HiSeq Illumina sequencer (125 nt paired end reads). Sequence assembly was performed using the de novo assembly tool in Geneious v8 at low sensitivity using $125 \mathrm{bp}$ read lengths. Two large contigs were generated with both returning significant matches to members of the Birnaviridae family by BLASTx.

RNA was extracted from a 1st passage stock of isolate 178287 using the Machery-Nagel Nucleospin viral RNA isolation kit as per the manufacturer's instructions. Purified RNA was sent to the Australian Genome Research Facility (Brisbane, Queensland) for sequencing using the Illumina HiSeq2000 platform. De novo assembled sequences for 177833 were then used as a scaffold to map reads from next-generation sequencing data for 178287 in Geneious v8.4.

MAFFT alignment was performed on 23 birnavirus polyprotein and $18 \mathrm{RdRP}$ amino acid sequences using the CIPRES gateway [35]. Amino acid alignments were used to construct maximum likelihood trees in MEGA 7.0.26 using the Jones-Taylor-Thornton model with gamma substitutions and no deletions. The corresponding nucleotide sequences for these proteins were aligned using the MUSCLE algorithm in Geneious Prime v2019.1.3. Phylogenetic analyses of nucleotide sequence alignments were performed in MEGA 7.0.26 using the general time-reversible (GTR) model with gamma distribution (5 categories $(+G$, parameter $=1.8479))$ and invariable variation for some sites $([+\mathrm{I}], 2.92 \%$ sites $)$.

Alignment of the ABV polyprotein and VP1 sequences with those of IPNV (PP: NP_047196, VP1: NP_047197), IBDV (PP: ANY27027, VP1: ANY27028), DXV (PP: NP_690836, VP1: NP_690806), RBV (PP: CAX33877, VP1: CAX33878), ESV (PP: AEW87521, VP1: AEW87520) and BSNV (PP: CAD30689, VP1: CAD30691) was performed using the ClustalW 2.1 alignment tool in Geneious Prime v2019.1.3.

Protein molecular weight predictions were performed using the ExPASy Compute $\mathrm{pI} / \mathrm{Mw}$ tool (https://web.expasy.org/compute_pi/).

\subsection{Cell Culture}

C6/36 (Ae. albopictus, RNAi-deficient) and Mos55 (Anopheles gambiae) cells were cultured in Roswell Park Memorial Institute 1640 (RPMI 1640) medium supplemented with 5\% fetal bovine serum (FBS). Chao ball (Culex tarsalis) and RML-12 (Ae. albopictus, RNAi competent) cells were maintained in Leibovitz-15 (L-15) medium supplemented with 10\% tryptose phosphate broth and 5\% FBS. All insect cells were incubated at $28{ }^{\circ} \mathrm{C}$. The vertebrate cell lines DF-1 (Gallus gallus, chicken embryo fibroblast), BSR (Mesocricetus auratus, baby hamster kidney), Vero (Cercopithecus aethiops, African green monkey kidney), A549 (Homo sapiens, human lung), SW13 (Homo sapiens, human adrenal gland/cortex), and IFNAR -/- MEFs (Mus musculus, mouse embryonic fibroblast, type 1 interferon receptor knockout) were maintained in Dulbecco's Modified Eagle Medium (DMEM) supplemented with 5\% FBS. Madin-Darby canine kidney (MDCK, Canis familiaris) cells were maintained in RPMI 1640 supplemented with 10\% FBS. Viper spleen-derived VSW cells (Daboia russelii, Russel's viper epithelial) were grown in Minimal Essential Media (MEM) with Hank's salts, $0.35 \mathrm{~g} / \mathrm{L}$ sodium bicarbonate, $10 \%$ FBS and amphotericin B. A6 (Xenopus laevis, South African clawed toad kidney epithelial) cells were maintained in RPMI 1640 with 10\% FBS and amphotericin B. All vertebrate cells were grown at $37{ }^{\circ} \mathrm{C}$ with $5 \% \mathrm{CO}_{2}$ except for VSW and $\mathrm{A} 6$ cells which were grown at $28{ }^{\circ} \mathrm{C}$ without $\mathrm{CO}_{2}$. All media were supplemented with $50 \mathrm{U} / \mathrm{mL}$ penicillin, $50 \mu \mathrm{g} / \mathrm{mL}$ streptomycin and $2 \mathrm{mM}$ L-glutamine.

\subsection{Virus Culture and Antigen Preparation}

Large-scale stocks of ABV isolate 177833 were generated by inoculating a 50\%-confluent T175 flask of C6/36 cells with passage 3 virus at a multiplicity of infection (MOI) of 0.1 and incubating at room temperature for $1 \mathrm{~h}$ with agitation. Inoculum was then removed and replaced with $18 \mathrm{~mL}$ RPMI 1640 with $2 \%$ FBS before incubating at $28^{\circ} \mathrm{C}$ for 7 days. Virus supernatant was harvested and clarified at $3000 \mathrm{rpm}$ at $4{ }^{\circ} \mathrm{C}$ for $15 \mathrm{~min}$, the FBS content was then increased to $10 \%$ before storing at $-80^{\circ} \mathrm{C}$ in $0.5 \mathrm{~mL}$ aliquots. 
ABV titers were determined with a modified TCID $_{50}$ method [36] using MAVRIC, as described in [26]. Briefly, 10-fold dilutions of virus (undiluted to 1:10 ${ }^{8}$ ) were added to C6/36 cells in 96 well plates and incubated for 7 days at $28^{\circ} \mathrm{C}$. Cells were fixed with $150 \mu \mathrm{L} /$ well formaldehyde fixative buffer ( $4 \%$ formaldehyde, $0.5 \% v / v$ Triton X-100 in phosphate-buffered saline, PBS) for 10 min at $4{ }^{\circ} \mathrm{C}$. After removing the fixative, plates were allowed to dry for at least 2 days before fixed-cell ELISA was performed using MAVRIC to test for viral replication as described in Section 2.1. Virus titers were calculated using the Reed-Muench guidelines [36].

Infected cells (approximately $10^{7.3}$ cells) from which virus stocks were generated were washed once with PBS and harvested by incubating with $3.5 \mathrm{~mL}$ NP-40 lysis buffer ( $1 \% \mathrm{NP}-40$ in $150 \mathrm{mM} \mathrm{NaCl}$, 50 mM Tris- $\mathrm{HCl}$ [pH 7.3], 1:100 protease inhibitor cocktail (P8340, Sigma, St Louis, MO, USA)) for 30 min at $4{ }^{\circ} \mathrm{C}$. Lysate was then clarified by centrifugation at $10,000 \mathrm{~g}$ for $10 \mathrm{~min}$ at $4{ }^{\circ} \mathrm{C}$ and stored at -80 ${ }^{\circ} \mathrm{C}$. Lysate aliquots were boiled before use for $10 \mathrm{~min}$ at $90^{\circ} \mathrm{C}$ to inactivate virus.

A preparation of ABV-infected cell culture supernatant with minimal FBS was generated using the protocol outlined above for production of virus stocks. However, after $5 \mathrm{dpi}$, the supernatant was removed and cells were washed 3 times with sterile PBS before the medium was replaced with $18 \mathrm{~mL}$ serum-free RPMI 1640. After another $48 \mathrm{~h}$, the serum-free supernatant was harvested and clarified by centrifugation and concentrated using a high-molecular-weight (100 K) MWCO Spin-X UF concentrator column (Corning, Deeside, England).

\subsection{ABV Purification and Analysis of Virions}

For purification, ten T175 flasks of C6/36 cells were infected with ABV at a MOI of 0.1 , as described above. After 7 days, supernatant was harvested and centrifuged at $3000 \mathrm{rpm}$ at $4{ }^{\circ} \mathrm{C}$ for $15 \mathrm{~min}$. Precipitation of virions was performed by mixing 2 parts clarified supernatant with 1 part $40 \%$ polyethylene glycol 6000 (PEG6000) solution at $4{ }^{\circ} \mathrm{C}$ overnight, followed by centrifugation at 12,000 rpm for $1 \mathrm{~h}$ at $4{ }^{\circ} \mathrm{C}$ using a Beckman Coulter JLA-16.250 rotor. Precipitated virus was then further purified through a $20 \%$ sucrose cushion in NTE buffer (10 mM Tris-Cl, $1 \mathrm{mM}$ EDTA, $120 \mathrm{mM} \mathrm{NaCl}$, $\mathrm{pH}$ 8), in a Beckman Coulter SW32 Ti rotor at $28,000 \mathrm{rpm}$ for $2 \mathrm{~h}$ at $4{ }^{\circ} \mathrm{C}$. The virus pellet was incubated in $500 \mu \mathrm{L}$ PBS overnight at $4{ }^{\circ} \mathrm{C}$ before resuspending. Finally, the virion preparation was layered onto a discontinuous gradient of 1.23 and $1.37 \mathrm{~g} / \mathrm{mL}$ cesium chloride $(\mathrm{CsCl})$ in PBS and centrifuged in a Beckman Coulter SW60 Ti rotor at $38,000 \mathrm{rpm}$ for $21 \mathrm{~h}$ at $15^{\circ} \mathrm{C}$. The resulting layer containing virus was extracted and buffer exchanged 3 times into PBS to remove residual $\mathrm{CsCl}$.

Purified virions were prepared for transmission electron microscopy (TEM) on glow-discharged carbon/formvar-coated copper grids and negatively stained with $1 \%$ uranyl acetate in ultrapure water. All imaging was performed on a JEOL 1011 transmission electron microscope. The average diameter of virions was determined using the ImageJ measurement tool

The infectivity of purified virions was assessed by inoculating C6/36 cells grown in triplicate in 24-well plates with approximately $3 \mu \mathrm{L}$ of purified virions diluted in $200 \mu \mathrm{L}$ culture medium per well, or virus culture supernatant at a MOI of 0.1. Inoculum was incubated on cells for $1 \mathrm{~h}$ at room temperature with agitation. After $1 \mathrm{~h}$ inoculum was removed, and cells were washed 3 times with PBS before replacing with $1 \mathrm{~mL}$ RPMI 1640 supplemented with 2\% FBS per well and incubating for 5 days at $28^{\circ} \mathrm{C}$. Virus titers were determined by the modified TCID 50 method described in Section 2.4.

\subsection{In Vitro Infectivity Assays}

Approximately $10^{5}$ cells were seeded onto glass coverslips in 24-well plates one day prior to infection. Triplicate wells were either inoculated with media only (mock control) or media containing $\mathrm{ABV}$ isolate 177833 at a MOI of 0.1 for $1 \mathrm{~h}$ at room temperature with agitation. Inoculum was then removed, and monolayers were washed 3 times with PBS before replacing with $1 \mathrm{~mL}$ per well of appropriate media with reduced FBS content (2\%). For DF-1, A6 and VSW cells, $1 \mathrm{~mL}$ of respective maintenance media described in Section 2.3 was used. 
For the mosquito cell assay, all cells were incubated at $28^{\circ} \mathrm{C}$ for 7 days while the vertebrate cell assay was performed at $37^{\circ} \mathrm{C}$ (or $28^{\circ} \mathrm{C}$ for VSW, A6 and C6/36 control cells) for 5 days. C6/36 cells were used as a control for infection in both assays. Supernatant was harvested $2 \mathrm{~h}$ post-infection (hpi) and both supernatant and coverslips were harvested 5 and 7 days post-infection (dpi) for the vertebrate and insect cells assay, respectively. Cell culture supernatants were assessed for virus by titrating back onto C6/36 cells, as described in Section 2.4.

\subsection{Immunofluorescence Assays}

For initial virus characterization and in vitro insect and vertebrate cell culture assays, cells grown on glass coverslips were washed once with PBS before fixing with $1 \mathrm{~mL}$ formaldehyde fixative buffer (described in Section 2.1) for $10 \mathrm{~min}$ at $4{ }^{\circ} \mathrm{C}$. After $10 \mathrm{~min}$, the fixative buffer was removed, and coverslips were allowed to dry at room temperature for at least 2 days. To investigate the effect of fixative method on MAVRIC immunolabeling, coverslips were washed once with PBS and fixed with formaldehyde fixative buffer, as described above, or by completely submerging the coverslip in ice-cold $100 \%$ acetone for $5 \mathrm{~min}$ and air drying at room temperature for $15 \mathrm{~min}$ before storing at $-20^{\circ} \mathrm{C}$.

Coverslips were incubated with $900 \mu \mathrm{L}$ TENTC blocking buffer for $1 \mathrm{~h}$ at room temperature. Primary antibody staining was performed by incubating with $300 \mu \mathrm{L}$ of MAVRIC or ABV-specific hybridoma supernatant (see Section 2.8) diluted in TENTC blocking buffer for $1 \mathrm{~h}$ at $37{ }^{\circ} \mathrm{C}$. Coverslips were washed 3x with PBS-T and stained with $150 \mu \mathrm{L}$ secondary antibody (Alexa Fluor 488-conjugated goat anti-mouse $(\mathrm{H}+\mathrm{L})$ or Alexa Fluor 594-conjugated goat anti-mouse $\operatorname{IgM}(\mu$ chain)) diluted 1:500 in TENTC blocking buffer for $1 \mathrm{~h}$ at $37^{\circ} \mathrm{C}$. Secondary antibody was removed and nuclear staining was performed with $150 \mu \mathrm{L}$ Hoechst 33342 for $5 \mathrm{~min}$ at room temperature, protected from light. Coverslips were washed 3x with PBST, followed by one wash with PBS (without Tween-20) and mounted on glass microscope slides using ProLong Gold Antifade mountant (ThermoFisher, Carlsbad, CA, USA). All coverslips were imaged using a Zeiss LSM 510 META confocal microscope.

\subsection{Generation and Characterization of Monoclonal Antibodies Raised to ABV}

All animal procedures had received prior approval from The University of Queensland Animal Ethics Committee (AEC \#SCMB/329/15/ARC) and, where necessary, were performed under ketamine:xylazine anaesthesia. Six-week-old BALB/c mice (Animal Resources Centre, Murdoch, Western Australia, Australia) were immunized twice two weeks apart via the subcutaneous route (s.c.) with purified ABV, along with inulin-based adjuvant Advax (Vaxine Ltd., Adelaide, Australia). Mice were kept on clean bedding and given food and water ad libitum. Immunized mice were bled via the tail vein at least two weeks following immunization and the sera tested for evidence of seroconversion to ABV using a fixed-cell ELISA as previously described [34]. Four days before fusions were performed, mice received a final boost via the intravenous route. For the first fusion, the mouse received a preparation of whole virus 4 months after the second s.c. injection. For the second fusion, the mouse received a preparation of purified virus which had been boiled at $90{ }^{\circ} \mathrm{C}$ for $10 \mathrm{~min}, 13$ months after the second s.c. immunization. Spleens were harvested under sterile conditions and processed by passing through a $70 \mu \mathrm{m}$ cell strainer with $10 \mathrm{~mL}$ RPMI. Fusion was induced between spleen cells and NS0 myeloma cells by the drop-wise addition of PEG-1500 (1g/mL in RPMI) at $37^{\circ} \mathrm{C}$. Fused cells were incubated overnight at $37^{\circ} \mathrm{C}$ with $5 \%$ $\mathrm{CO}_{2}$ in a conditioned flask. Selection for hybridomas was performed by the addition of HAT supplement (hypoxanthine, aminopterin, thymidine; Hybri-Max, Sigma-Aldrich) and cells were plated in 96-well plates [37]. Hybridomas secreting ABV-reactive antibodies were identified by ELISA on ABV-infected $\mathrm{C} 6 / 36$ cell plates, as described in Section 2.1. However, initial screening was performed on plates fixed overnight at $4{ }^{\circ} \mathrm{C}$ with $200 \mu \mathrm{L} /$ well acetone fixative buffer (20\% $v / v$ acetone, $0.02 \% w / v$ bovine serum albumin (BSA) in PBS).

Antibody isotyping was performed using Mouse Monoclonal Antibody Isotyping Reagents (Sigma-Aldrich, ISO2), as described previously [32]. 
Mouse immune serum and mAbs were tested against ABV-infected cell lysate by Western blot, as described previously $[27,28]$. Immune serum was also tested against purified virions, virus stock supernatant, and virus grown in minimal serum by Western blot.

Microneutralization assays were performed using 2-fold dilutions of hybridoma culture supernatant (1:2-1:256) or mouse immune serum (1:20-1:2480) and MAVRIC ELISA was used to measure neutralization effect, as described in [27].

\subsection{Protein Analysis and Mass Spectrometry for Protein Identification}

Purified virions were reduced with $80 \mathrm{mM}$ DTT and boiled at $90{ }^{\circ} \mathrm{C}$ for $3 \mathrm{~min}$ before protein separation on precast $4-12 \%$ Bis-Tris SDS-PAGE gels (NuPAGE, ThermoFisher Scientific) at 175 volts for $45 \mathrm{~min}$. Separated proteins were stained using SYPRO Ruby protein gel stain (ThermoFisher Scientific) as per the manufacturer's instructions and visualized under UV light. Molecular weights of separated proteins were determined by relative mobility (Rf) analysis.

Protein bands which could be visualized by eye were excised and de-stained in a solution of $50 \%$ acetonitrile $(\mathrm{ACN})$ in $50 \mathrm{mM}$ ammonium bicarbonate $(\mathrm{ABC})$ overnight at $37^{\circ} \mathrm{C}$ with shaking. Gel slices were treated with $10 \mathrm{mM}$ DTT at $60^{\circ} \mathrm{C}$ for $30 \mathrm{~min}$, and then alkylated in a $30 \mathrm{mM}$ acrylamide solution for $30 \mathrm{~min}$ at room temperature, protected from light. The gel slices were then washed twice with $50 \mathrm{mM}$ ABC and dehydrated with $100 \% \mathrm{ACN}$. Proteins were digested with $80 \mathrm{ng}$ of trypsin (New England BioLabs) in $50 \mathrm{mM} \mathrm{ABC}$ at $37^{\circ} \mathrm{C}$ overnight. Peptides were extracted by sonication of the gel slices in a solution of $50 \% \mathrm{ACN}$ with $0.1 \%$ formic acid (FA).

For in-solution digestions, purified virions were denatured in a solution of $8 \mathrm{M}$ urea in $50 \mathrm{mM}$ $\mathrm{ABC}$ and centrifuged at $14,000 \mathrm{~g}$ for $10 \mathrm{~min}$ to remove debris. Samples were reduced in $5 \mathrm{mM}$ DTT at $56^{\circ} \mathrm{C}$ and alkylated with $25 \mathrm{mM}$ iodoacetamide for $30 \mathrm{~min}$ at room temperature. Excess iodoacetamide was quenched by another addition of DTT to a final concentration of $5 \mathrm{mM}$. Samples were diluted in 50 $\mathrm{mM} \mathrm{ABC}$ to bring the concentration of urea below $2 \mathrm{M}$. Approximately $12 \mu \mathrm{g}$ of protein was incubated with $120 \mathrm{ng}$ trypsin $(1: 100)$ or $60 \mathrm{ng}$ chymotrypsin $(1: 200)$ overnight at $37^{\circ} \mathrm{C}$.

Ziptip (Millipore) cleanup was performed on all samples to remove impurities. Peptides were eluted in $0.1 \%$ FA and run on both the Orbitrap Elite and Triple Tof 5000 mass spectrometers. Data was analyzed with ProteinPilot software (SCIEX) using databases containing Ae. albopictus proteins and ABV polyprotein and RdRP amino acid sequences.

Identified peptides mapping to the ABV polyprotein with $>50 \%$ confidence were further assigned to individual proteins (pVP2, VP3, VP4) manually in Excel based on the predicted sequence for each protein.

Mass spectrometry analysis for glycopeptide analysis is described in detail in Appendix A.

\section{Results}

\subsection{Detection of Two Isolates of a Novel Virus with Distinctive dsRNA Immunostaining}

During routine mosquito collections for arbovirus surveillance in NSW, Australia, 45 mosquito pools were identified as positive for unidentified viruses via detection of dsRNA in inoculated C6/36 cells by ELISA, using the MAVRIC system. The pools were further analyzed by a combination of fixed-cell ELISA using virus-specific mAbs and RT-PCR using virus-specific primers to detect selected ISVs known to circulate in Australian mosquito populations (Table S1). This analysis identified 14 isolates of Liao ning virus (LNV), including one pool co-infected with Alphamesonivirus 1 (Nam Dinh virus, NDiV), which was first reported in Prow et al. [28] (Figure 1a). A subset of the remaining pools, which were negative for the tested ISVs, were selected for further analysis with MAVRIC in IFA. Two pools of Ae. notoscriptus mosquitoes collected in Ballina, NSW (177833 and 178287) shared a unique punctate, cytoplasmic dsRNA-staining pattern (Figure 1a,b). Next-generation sequencing of the two pools identified a birnavirus-like sequence with $37.52 \%$ identity to the RdRP of Rotifer birnavirus (RBV) by Blastx analysis (e-value 4e-138). This virus was tentatively named Aedes birnavirus (ABV). 
Comparison of the sequences from both pools showed high similarity at the nucleotide level (99.95\% Segment A, 99.93\% Segment B), suggesting that isolates 177833 and 178287 were likely of the same virus strain. No overt cytopathic effect (CPE) was observed in C6/36 cells infected with either isolate of ABV, while cells inoculated with the Ae. notoscriptus pool containing LNV and NDiV (179853) exhibited clearance of the monolayer (Figure 1c). No evidence of co-infection with other known viruses was observed for either pool containing ABV. Using ABV-specific primers (Table S1), retrospective RT-PCR screening was performed on the 45 MAVRIC-positive unknown pools from NSW, along with selected Aedes mosquito pools from the Northern Territory and Western Australia, which were found to be MAVRIC positive but negative for all tested ISVs. However, no further isolates of ABV were identified (Figure 1a, Figure S1).

\begin{tabular}{|c|c|c|c|c|}
\hline Mosquito species & Location & $\begin{array}{c}\text { Collection } \\
\text { year }\end{array}$ & $\begin{array}{l}\text { ABV positive*/ } \\
\text { MAVRIC positive }\end{array}$ & $\begin{array}{c}\text { Other virus ID } \\
\text { (no. positive/no. tested) }\end{array}$ \\
\hline \multirow{2}{*}{ Aedes notoscriptus } & Ballina & 2013 & $2 / 3$ & LNV, NDiV $(1 / 3)^{\dagger \ddagger}$ \\
\hline & Lake Macquarie & 2013 & $0 / 1$ & - \\
\hline Ae. alternans & Bankstown & 2014 & $0 / 1$ & - \\
\hline \multirow{8}{*}{ Ae. vigilax } & Bankstown & 2013 & $0 / 1$ & $\operatorname{LNV}(1 / 1)$ \\
\hline & Homebush bay & 2013 & $0 / 5$ & $\operatorname{LNV}(2 / 5)$ \\
\hline & Bankstown & 2014 & $0 / 1$ & - \\
\hline & Homebush bay & 2014 & $0 / 10$ & $\operatorname{LNV}(1 / 10)$ \\
\hline & Georges River & 2014 & $0 / 4$ & $\operatorname{LNV}(1 / 4)$ \\
\hline & Tweed Heads & 2014 & $0 / 2$ & $\operatorname{LNV}(1 / 2)$ \\
\hline & Port Stephens & 2014 & $0 / 10$ & $\operatorname{LNV}(3 / 10)$ \\
\hline & Central Coast & 2014 & $0 / 2$ & $\operatorname{LNV}(1 / 2)$ \\
\hline Anopheles annulipes & Leeton & 2014 & $0 / 1$ & - \\
\hline \multirow{2}{*}{ Culex annulirostris } & Tweed Heads & 2013 & $0 / 1$ & - \\
\hline & Griffith & 2013 & $0 / 2$ & $\operatorname{LNV}(2 / 2)$ \\
\hline Cx. quinquefasciatus & Murray & 2013 & $0 / 1$ & $\operatorname{LNV}(1 / 1)$ \\
\hline
\end{tabular}

$$
\text { (b) }
$$

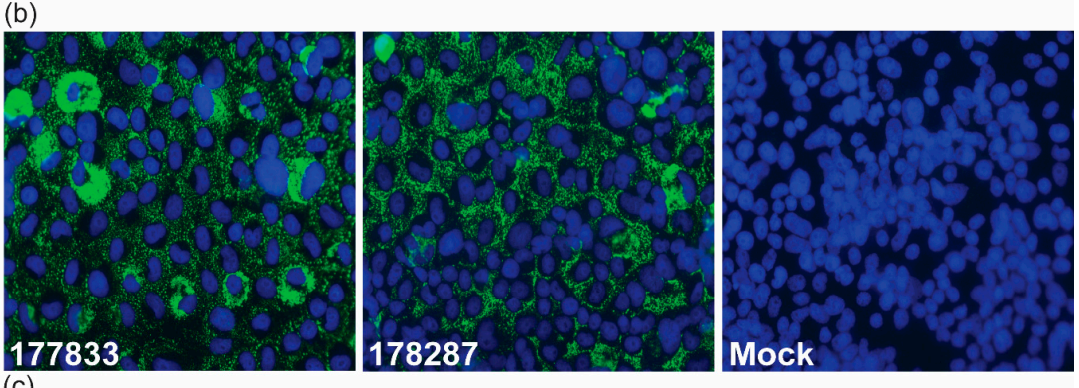

(c)

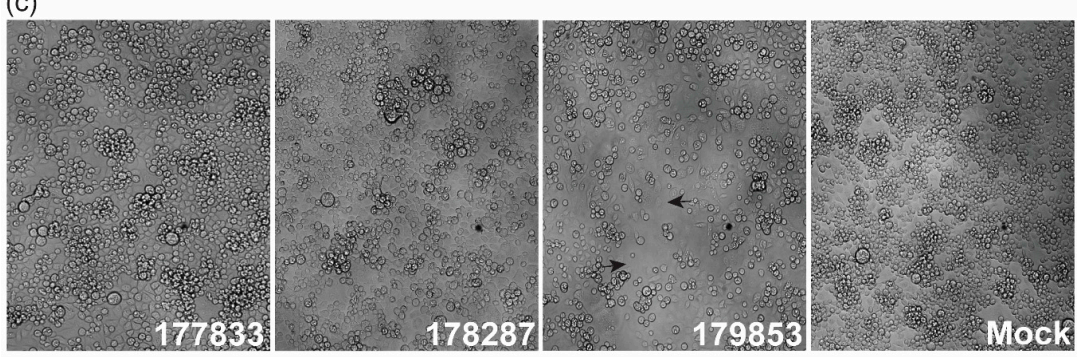

Figure 1. Isolation and prevalence of Aedes birnavirus (ABV). (a) Summary of screening for ABV and known insect-specific viruses (ISVs) in MAVRIC-positive mosquito pools collected in NSW between 2013 and 2014. (b) Anti-double-stranded RNA (dsRNA) immunolabeling in C6/36 cells inoculated with mosquito pools 177833 and 178287, or mock infected (media only) in immunofluorescence assay. Images were taken at $63 \times$ magnification. Green: dsRNA. Blue: nuclei. (c) C6/36 cells infected with ABV isolates 177833 and 178287, NDiV/LNV co-infected isolate 179853 and mock-infected cells. Gaps in the monolayer typical of NDiV/LNV infection are depicted by arrows for isolate 179853. Cell monolayer images were taken at 20x magnification. * Screened by RT-PCR with ABV-specific primers. The $\dagger$ LNV/NDiV-positive pool did not contain ABV. $\ddagger$ Ballina LNV/NDiV isolate originally reported in Prow et al. [28]. 


\subsection{Phylogenetic Analysis}

The segment A of ABV possesses $45.6 \%$ GC content and does not contain the slippery UUUUUUAA motif which is conserved among entomobirnaviruses $[17,18,20]$. Segment A gives rise to a polyprotein of 1239 amino acids, larger than the typical range of 972-1114 amino acids reported in other birnavirus polyproteins. Segment B has a GC content of $43.9 \%$ and encodes a VP1 which is 904 amino acids in length. The VP1 of ABV does not contain the large C-terminal domain which is present in RBV and the entomobirnaviruses (Figure S2) [2].

Phylogenetic analyses of both the nucleotide and amino acid sequences of VP1 and the amino acid sequence of the polyprotein indicated that $\mathrm{ABV}$ forms a well-supported clade with RBV, indicating a possible distant taxonomic association with this virus (Figure 2a,b, Figure 3b). Nucleotide-based phylogenetic analyses of the polyprotein showed ABV clustered with the Entomobirnavirus genera. However, this position was not as strongly supported (bootstrap value of 54\%) (Figure 3a).
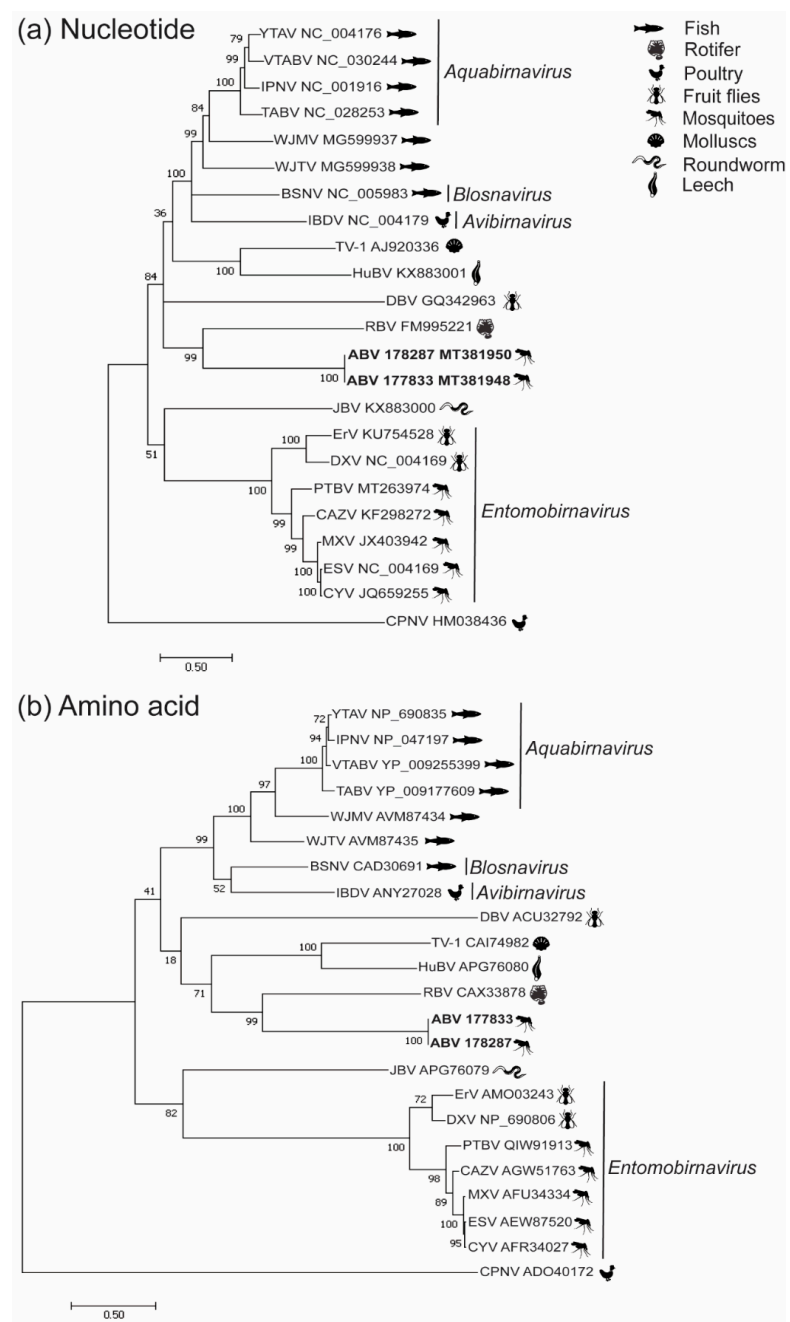

Figure 2. Phylogenetic analysis of ABV VP1. Unrooted maximum likelihood trees constructed from (a) VP1 nucleotide coding sequences (CDS) aligned using the MUSCLE algorithm and (b) VP1 amino acid sequences aligned with MAFFT. The broad host-species classification for each virus is indicated by icons next to the virus name. Currently recognized genera are indicated in italics. Maximum likelihood analyses were performed in MEGA 7.0.26 using the general time-reversible (GTR) model with gamma distribution $(5$ categories $(+\mathrm{G}$, parameter $=1.8479)$ ) and invariable variation for some sites $([+\mathrm{I}], 2.92 \%$ sites) for nucleotide sequences and the Jones-Taylor-Thornton (JTT) model with gamma substitutions and no deletions for amino acid sequences. 

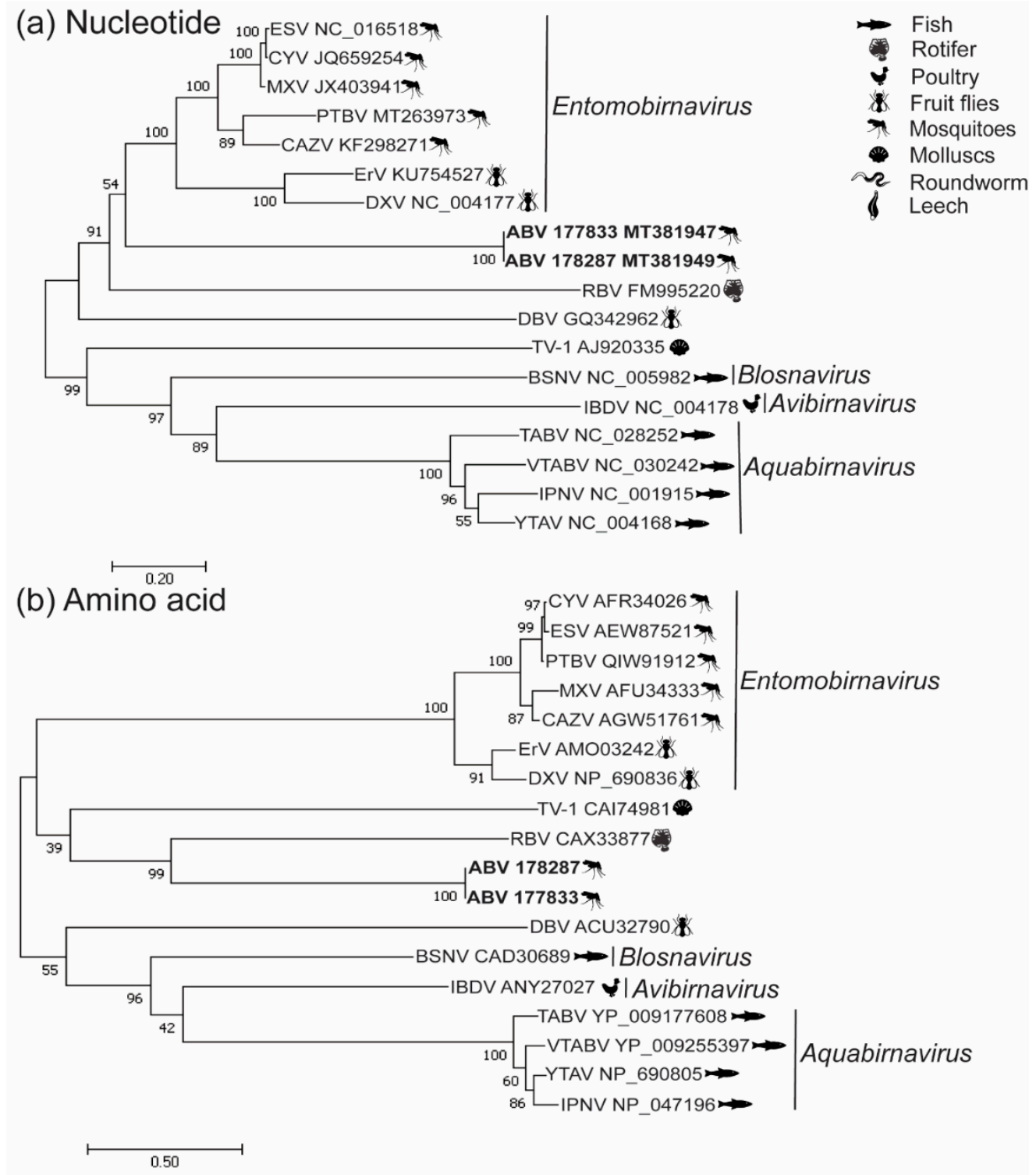

Figure 3. Phylogenetic analysis of ABV polyprotein. Unrooted maximum likelihood trees constructed from (a) nucleotide coding sequences (CDS) for birnavirus polyproteins aligned using the MUSCLE algorithm and (b) polyprotein amino acid sequences aligned with MAFFT. The broad host-species classification for each virus is by icons next to the virus name. Currently recognized genera are indicated in italics. Maximum likelihood analyses were performed in MEGA 7.0.26 using the general time-reversible (GTR) model with gamma distribution (5 categories ( + G, parameter $=1.8479)$ ) and invariable variation for some sites $([+\mathrm{I}], 2.92 \%$ sites $)$ for nucleotide sequences and the Jones-Taylor-Thornton (JTT) model with gamma substitutions and no deletions for amino acid sequences.

\subsection{Analysis of ABV Structural Proteins}

Transmission electron microscopy (TEM) on purified ABV revealed icosahedral particles with average diameters ranging from 64 to $70 \mathrm{~nm}$ (Figure 4a). Inoculation of C6/36 cells with two independently purified virus preparations indicated that the purified particles were infectious (Figure $4 \mathrm{~b}$ ). SDS-PAGE analysis of the purified virions revealed 2 major bands at approximate molecular weights of 38 and $28 \mathrm{kDa}$ which were determined by mass spectrometry to contain VP3 and VP4, respectively (Figure 4c). Less-prominent bands were identified at approximate molecular weights of $113 \mathrm{kDa}$ corresponding to the RdRP and 15, 16 and $7.5 \mathrm{kDa}$ likely to be peptides derived 
from the C-terminus of pVP2 (Figure 4c). A distinct band at the expected size range for the mature birnavirus VP2 (40-55 kDa) was not identified [4,6,16,38,39]. Instead, peptides mapping to ABV VP2 were only identified in bands running at apparent molecular weights of 150, 113 and $70 \mathrm{kDa}$ (Figure 4c, Supplementary File S1). While our mass spectrometry analyses resulted in high coverage for VP3 and VP4 (93.8\% and 84.5\% respectively), the coverage for pVP2 was much lower (31.9\%) (Figure 4c). Further denaturation of virions in $3 \mathrm{M}$ urea did not alter the banding pattern of ABV proteins in SDS-PAGE, suggesting that the larger-than-expected size for VP2 was not due to dimerization of the protein (Figure $4 \mathrm{~d}$ ).

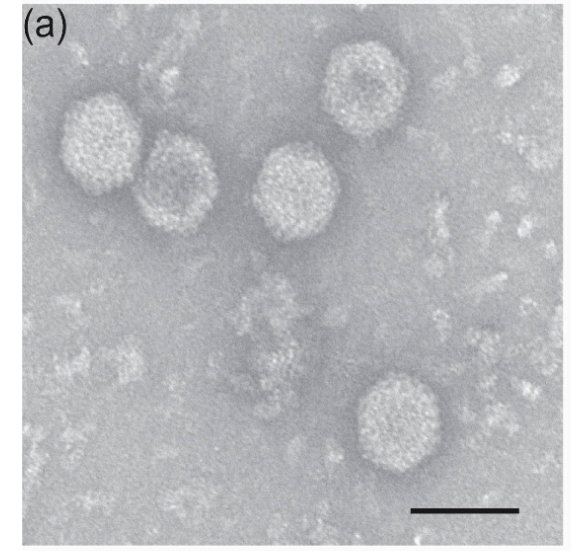

(c)

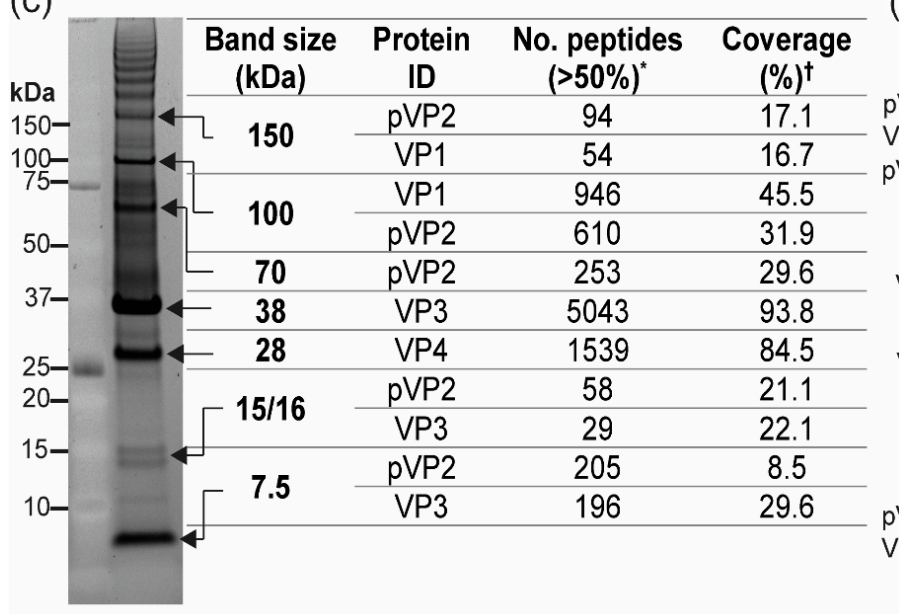

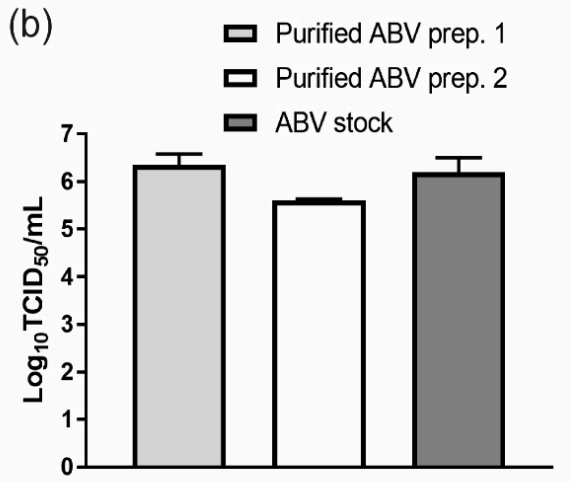

(d)

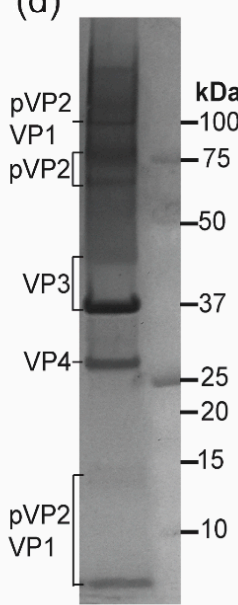

Figure 4. Protein analysis of ABV. (a) Transmission electron micrograph of purified ABV particles negatively stained with uranyl acetate and imaged at $200 \mathrm{~K}$. Scale bar represents $100 \mathrm{~nm}$. (b) Infectivity of two preparations of $\mathrm{CsCl}$ gradient-purified $\mathrm{ABV}$ particles in $\mathrm{C6} / 36$ cells as compared to $\mathrm{ABV}$-infected cell supernatant used at a known MOI (0.1). Values graphed are averaged virus titers in supernatants taken from infected cells at 7 days post-infection (dpi). Error bars represent standard deviation in titers between 3 replicate wells. (c) Ruby stained image of SDS-PAGE analysis on purified ABV boiled and reduced with $1 \mathrm{M} \mathrm{DTT}$, and results of mass spectrometry identification of excised protein bands as indicated by arrows. Protein ID refers to top ranking proteins identified in each band by mass spectrometry analysis. ${ }^{*}$ No. peptides, number of peptides identified with equal to or greater than $50 \%$ confidence; ${ }^{\dagger}$ Coverage, percentage of protein covered by peptides identified with $>50 \%$ confidence. (d) Ruby stained image of SDS-PAGE analysis of ABV further denatured in $3 \mathrm{M}$ urea. Protein identities based on mass spectrometry are indicated next to each band. Kaleidoscope protein ladder was run alongside all samples. 


\subsection{ABV Proteins Demonstrate Trypsin Resistance}

Due to the lower coverage of VP2 observed in mass spectrometry analysis, the predicted peptides generated from trypsin cleavage of the polypeptide were investigated with ExPASy PeptideCutter. This analysis showed a lack of cleavage sites for trypsin in the predicted pVP2 sequence of ABV which resulted in generation of large peptides (23-97 aa) (Supplementary File S2) which would be unlikely to be detected by mass spectrometry. To confirm this, side-by-side digestions using trypsin and chymotrypsin were performed on whole virions. Mass spectrometry analysis of the resulting peptides showed that while digestion with chymotrypsin resulted in higher coverage of all ABV proteins when compared to trypsin, this difference was most striking for pVP2 with a $35.9 \%$ increase (trypsin, 34.9\% to chymotrypsin, 70.8\%) (Table 1, Figure 5). This indicated that trypsin was not optimal for proteolytic digestion of ABV pVP2. However, due to its low cleavage site fidelity, chymotrypsin was deemed an unsuitable alternative for mass spectrometry analysis [40].

Table 1. Mass spectrometry analysis of peptides produced by digestion of ABV whole virions by trypsin or chymotrypsin.

\begin{tabular}{ccccc}
\hline \multirow{2}{*}{ Protein Identified } & \multicolumn{2}{c}{ Trypsin } & \multicolumn{2}{c}{ Chymotrypsin } \\
\cline { 2 - 5 } & No. Peptides (50\%) * & \% Coverage (50) ${ }^{\dagger}$ & No. Peptides (50\%) $^{*}$ \% Coverage (50) $^{\dagger}$ \\
\hline VP1 & 161 & 38.4 & 145 & 43.04 \\
Polyprotein & 605 & 54.7 & 476 & 74.6 \\
pVP2 & 197 & 34.9 & 250 & 70.8 \\
VP3 & 237 & 60.6 & 108 & 82.08 \\
VP4 & 171 & 83.7 & 109 & 84.09 \\
\hline
\end{tabular}

* No. peptides (50\%), number of distinct peptides with at least $50 \%$ confidence; ${ }^{+} \%$ coverage $(50)$, percentage of matching amino acids from identified peptides with equal to or greater than $50 \%$ confidence divided by total no. amino acids in protein sequence.

\subsection{Sequence Analysis of ABV Polyprotein}

In order to identify potential cleavage sites in the ABV polyprotein, amino acid sequence alignment was performed with the polyprotein sequences of ESV and birnaviruses for which cleavage sites have been experimentally determined [16,41,42]. Based on known cleavage sites for these viruses, the C-terminus of the mature ABV capsid protein was predicted at amino acid 437, giving rise to a protein with an estimated molecular weight of $47.2 \mathrm{kDa}$ (Figure 6). Analysis of the polypeptide revealed two insertions of 61 and 85 amino acids between VP2 and VP4 which were not conserved in the other birnaviruses. The resulting $\mathrm{pVP} 2$ protein had a predicted molecular weight of $72.6 \mathrm{kDa}$, consistent with the size range at which we detected pVP2 peptides in SDS-PAGE analysis (Figure 4). Furthermore, peptides mapping to these inserted regions were detected during mass spectrometry analysis performed on both gel slices after SDS-PAGE separation and purified virions (Figure 5, Supplementary Files S1 and S2). No strong evidence of N- or O-linked glycans on any ABV proteins could be found using mass spectrometry (Supplementary Files S3 and S4). Sequential proteolytic digestion of $\mathrm{ABV}$ virions by Glu-C and trypsin did not improve coverage of pVP2 (Supplementary Files S3 and S4).

\subsection{Production of Monoclonal Antibodies to $A B V$}

To aid in additional screening for, and characterization of, $\mathrm{ABV}$, purified virions were used to immunize mice for the production of polyclonal antisera and mAbs. Mouse immune serum raised to ABV was tested in Western blot against virus culture supernatant prepared with minimal serum content, virus stock supernatant and two preparations of purified ABV under unreduced or boiled and reduced conditions (Figure 7a). This analysis showed VP3 (approximate molecular weight of $38 \mathrm{kDa}$ ) to be the immunodominant protein in all preparations. The anti-ABV serum also displayed reactivity to a 50-60 kDa protein in cell culture supernatants, which was not observed in either preparation of purified virions. This protein most likely represents a component of FBS which was present at low 
levels $(<1 \%$ ) in concentrated virus supernatant (sample 1 ) and at $10 \% v / v$ in virus stock supernatant (sample 2) (Figure 7a). The anti-ABV mouse immune serum had a strong neutralizing effect on ABV, inhibiting replication at all tested dilutions (1:20 to 1:2480).

\section{(a) Trypsin}

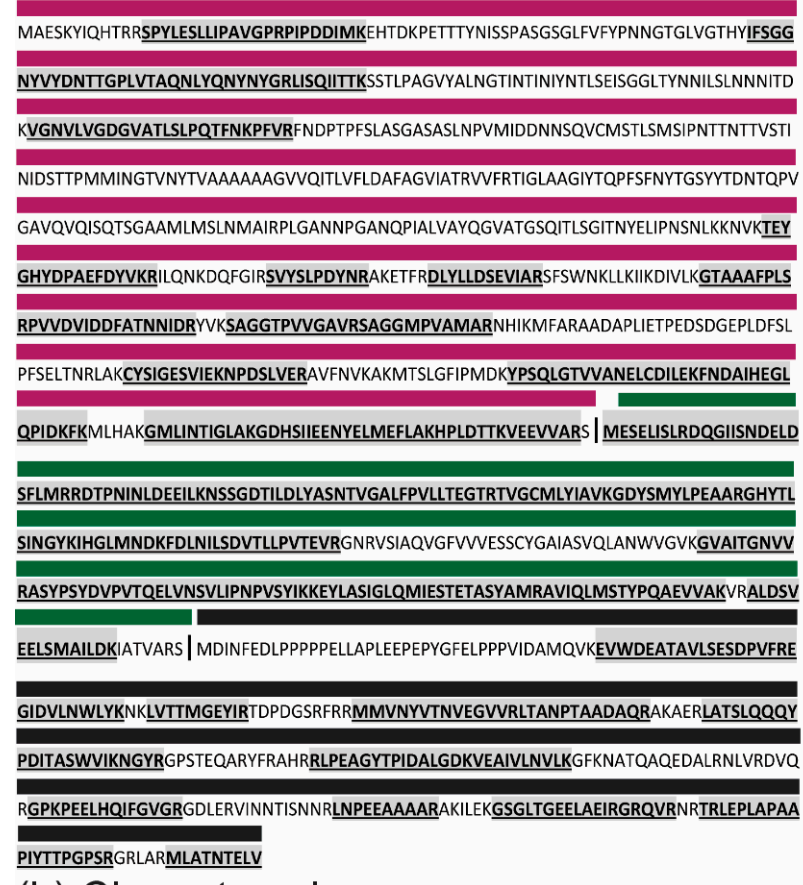

\section{(b) Chymotrypsin}

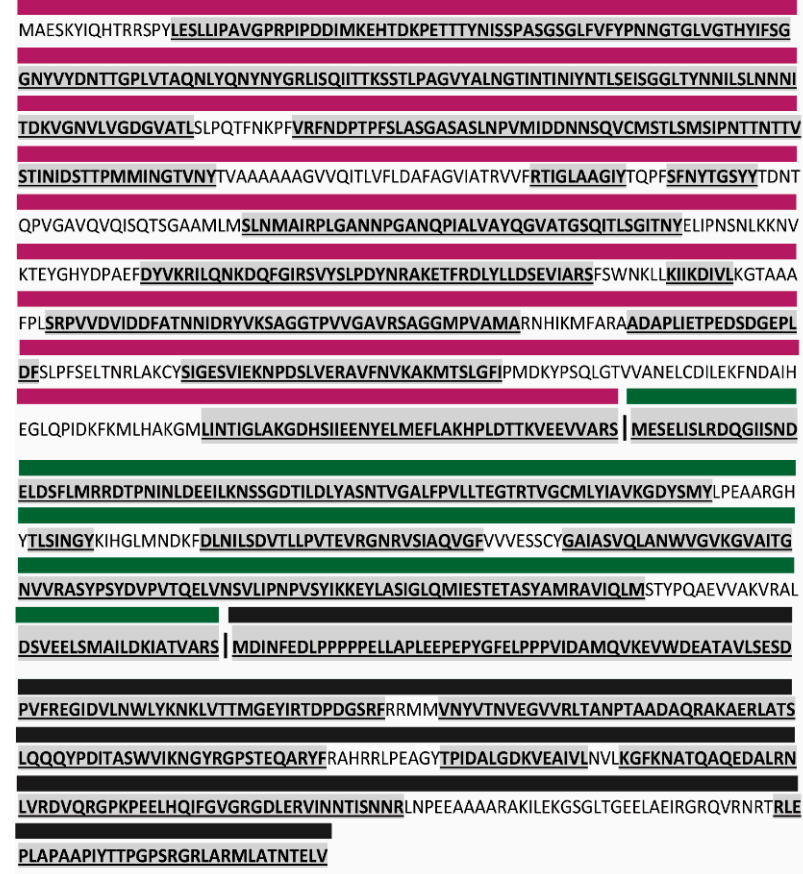

Figure 5. Digestion of ABV proteins by trypsin and chymotrypsin. Schematic showing ABV polyprotein sequence identified by mass spectrometry following digestion with (a) trypsin or (b) chymotrypsin. Sequence detected by mass spectrometry is highlighted in grey and underlined. Colored bars above sequence denote predicted individual proteins: pVP2, magenta; VP4, green; VP3, black. 


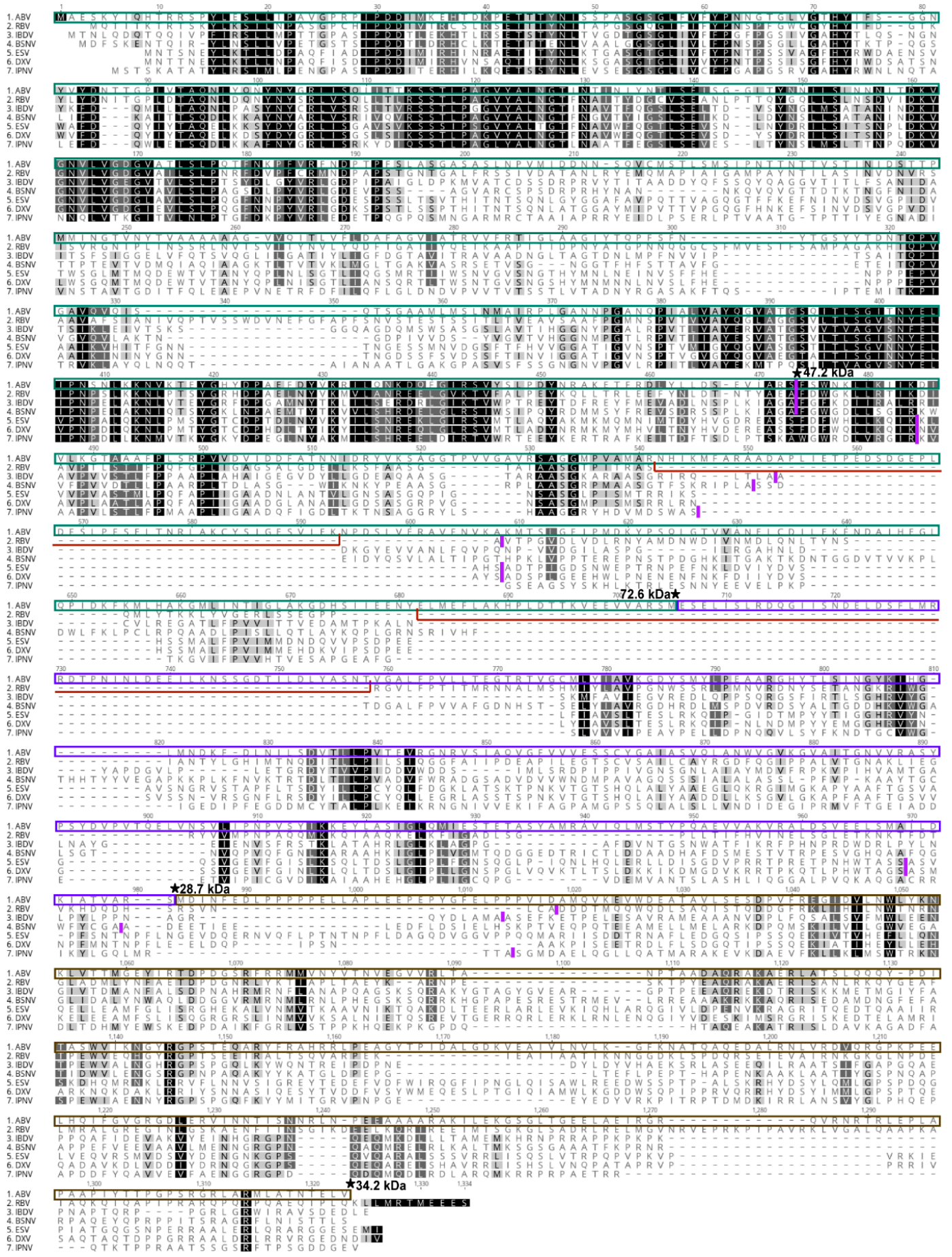

Figure 6. Clustal $\mathrm{W}$ alignment of amino acid polyprotein sequences for ABV, RBV (CAX33877), IBDV (ANY27027), BSNV (CAD30689), ESV (AEW87521), DXV (NP_690836) and IPNV (NP_047196). Non-conserved insertions of 61 and 85 amino acids in the ABV polyprotein are indicated by red lines. Vertical lines in magenta depict published polyprotein cleavage sites for these birnaviruses [41,42]. $\star$ Denotes predicted cleavage sites for ABV based on mass spectrometry data; Molecular weights predicted using ExPASy compute $\mathrm{pI} / \mathrm{MW}$ tool are marked at the c-terminus of each resulting protein. Green box, pVP2. Purple box, VP4; brown box, VP3. 


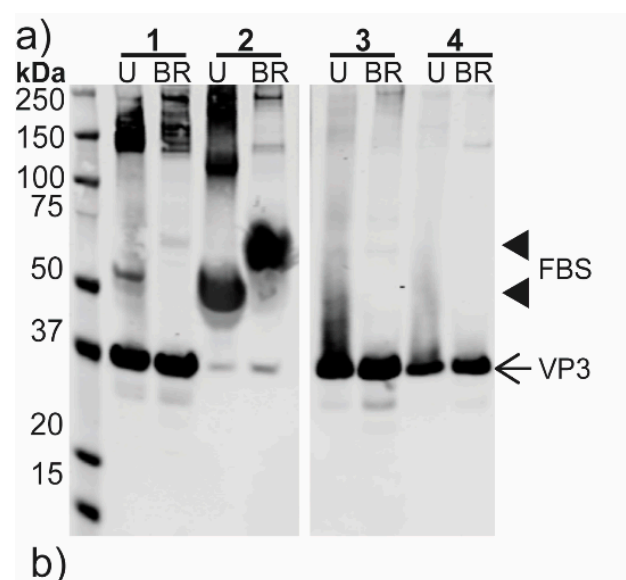

\begin{tabular}{|c|c|c|c|c|}
\hline $\begin{array}{l}\text { Monoclonal } \\
\text { antibody }\end{array}$ & Isotype & $\begin{array}{l}\text { Target } \\
\text { antigen }\end{array}$ & $\begin{array}{l}\text { Reactivity to } \\
\text { formaldehyde- } \\
\text { fixed epitopes }\end{array}$ & $\begin{array}{l}\text { Neutralisation } \\
\text { activity }\end{array}$ \\
\hline A1C11 & $\lg G 1$ & VP3 & + & $<2^{*}$ \\
\hline A1D6 & $\lg G 1$ & VP3 & + & $<2$ \\
\hline A2B3 & $\operatorname{lgG1}$ & Unknown & + & $<2$ \\
\hline A2E2 & $\lg G 1$ & VP3 & - & $<2$ \\
\hline A3G2 & $\lg G 2 b$ & VP3 & + & $<2$ \\
\hline A4G7 & $\lg G 2 a$ & $\mathrm{VP}^{\dagger}$ & + & 256 \\
\hline A6B2 & $\lg G 1$ & VP3 & + & $<2$ \\
\hline A6B8 & $\lg M$ & VP3 & - & $<2$ \\
\hline A6D4 & $\lg G 1$ & VP3 & + & $<2$ \\
\hline A6F6 & $\lg M$ & $\mathrm{VP}^{\dagger}$ & + & 64 \\
\hline A6F10 & $\operatorname{lgM} / \lg G 2 a$ & Unknown & + & $<2$ \\
\hline A7E6 & $\lg G 2 a$ & VP3 & $+/-$ & $<2$ \\
\hline A7F11 & $\lg M$ & VP3 & + & $<2$ \\
\hline
\end{tabular}

*Neutralisation titre taken at the reciprocal dilution at which all virus replication is inhibited. †Most likely reactive protein based on neutralising activity.

Figure 7. Antibody response to ABV. (a) Reactivity of anti-ABV mouse immune serum to ABV in Western blot. Lane 1, supernatant from ABV-infected C6/36 cells grown in minimal (<1\%) FBS; 2, $\mathrm{ABV}$ virus stock supernatant from $\mathrm{C} 6 / 36$ cells, supplemented with $10 \% \mathrm{FBS} ; 3, \mathrm{CsCl}$ gradient-purified preparation one of ABV in PBS; 4, CsCl gradient-purified preparation two of ABV in PBS. U, unreduced; BR, boiled and reduced. (b) Summary of ABV-specific monoclonal antibody panel. + Most likely target based on neutralizing activity. * Highest reciprocal dilution at which virus infectivity is inhibited. -, OD450 $\mathrm{nm}<0.25$ and less than two times the average OD of the negative control; +, OD450 nm is $>0.5$ and at least two times greater than the average OD of negative control; +/-, positive result but inconsistent between replicates.

Two hybridoma fusions using the spleens from immunized mice resulted in a panel of 13 mAbs with specificity to ABV in $20 \%$ acetone fixed-cell ELISA. Nine of the $13 \mathrm{mAbs}$ were found to bind to VP3 in Western blot, consistent with the binding profile observed for the polyclonal serum (Figure $7 \mathrm{~b}$ ). The remaining four $\mathrm{mAbs}$ did not react in Western blot and may bind conformational or SDS-sensitive epitopes. Two mAbs, A4G7 and A6F6, were shown to have neutralizing capabilities in microneutralization assays and, based on this property, are predicted to bind the capsid protein VP2 (Figure 7b). Neither A4G7 nor A6F6 reacted in Western blot. None of the mAbs which reacted to VP3 in Western blot showed any neutralizing activity. As acetone fixative buffer is not optimal for inactivation of non-enveloped viruses, the anti-ABV mAbs were tested for use with formaldehyde fixation. This testing found 11 of the $13 \mathrm{mAbs}$ were reactive against formaldehyde-fixed epitopes in fixed-cell ELISA (Figure 7b).

\subsection{ABV Does Not Replicate in Vertebrate Cells In Vitro}

$\mathrm{ABV}$ was tested for replication in a panel of vertebrate cell lines derived from mammalian, avian, amphibian and reptilian origins. At $5 \mathrm{dpi}$, no viable virus could be recovered from supernatants 
harvested from SW13, BSR, A459, IFNAR-/- MEFs, MDCK or VSW cells (Table 2, Figure S3). Low levels of virus were detected in DF-1, Vero and A6 cell supernatant at 5 dpi. However, viral titers in these supernatants were lower than that of supernatants harvested at $2 \mathrm{hpi}$, suggesting that this represented residual virus of the inoculum rather than productive replication. Supporting this, no dsRNA could be identified in any of the vertebrate cell lines by IFA at 5 dpi (Figure S3). This suggests ABV possesses an insect-specific phenotype and reflects the findings for other birnaviruses isolated from mosquitoes.

Table 2. Summary of findings for ABV infection of vertebrate cells.

\begin{tabular}{|c|c|c|c|c|}
\hline \multirow{2}{*}{ Cell Line } & \multirow{2}{*}{ Cell Origin } & \multirow{2}{*}{ ABV Replication } & \multicolumn{2}{|c|}{ Mean Titer Recovered $(/ \mathrm{mL})^{\dagger}$} \\
\hline & & & $2 \mathrm{hpi}$ & $5 \mathrm{dpi}$ \\
\hline DF-1 & Avian & - & $10^{1.8}$ & $10^{0.87}$ \\
\hline Vero & Monkey & - & $10^{1.8}$ & $10^{1.41}$ \\
\hline SW13 & Human & - & $10^{1.3}$ & $<10^{1.3 *}$ \\
\hline A549 & Human & - & $10^{1.78}$ & $<10^{1.3}$ \\
\hline MDCK & Canine & - & $10^{1.05}$ & $<10^{1.3}$ \\
\hline BSR & Rodent & - & $10^{2.02}$ & $<10^{1.3}$ \\
\hline $\begin{array}{c}\text { MEF } \\
\text { IFNAR }^{-/-}\end{array}$ & Rodent & - & $10^{1.11}$ & $<10^{1.3}$ \\
\hline VSW & Reptile & - & $10^{1.71}$ & $<10^{1.3}$ \\
\hline A6 & Amphibian & - & $10^{1.71}$ & $10^{1.45 \#}$ \\
\hline C6/36 & Mosquito & + & $10^{2.13}$ & $10^{5.8}$ \\
\hline
\end{tabular}

${ }^{\dagger}$ Mean titer $\left(\mathrm{TCID}_{50} / \mathrm{mL}\right)$ averaged across three replicates per time point. ${ }^{*}$ Limit of detection. ${ }^{\text {\# }}$ Virus detected in two of three replicates. -, ABV did not replicate; +, ABV replication; hpi, hours post-infection; dpi, days post-infection.

\subsection{ABV Displays Aedes-Specific Tropism In Vitro}

While some ISVs are highly specific for a single mosquito species or genera [25,30,43], others show the ability to infect a broad range of mosquito species [27-29,33]. Therefore, ABV was assessed for replication in cell lines derived from Aedes, Culex and Anopheles mosquitoes. IFA revealed cytoplasmic dsRNA staining in RML-12 cells (Ae. albopictus, RNAi-competent) like that observed in C6/36 cells (Ae. albopictus, RNAi-deficient) (Figure 8a). In contrast, infected Chao Ball (Cx. tarsalis) and Mos55 (An. gambiae) cells were characterized by a single focus of perinuclear dsRNA staining (Figure 8a, inset). ABV replicated in RML-12 cells to an average titer of $10^{5.7} / \mathrm{mL}$ by $7 \mathrm{dpi}$, approximately 1 log lower than the mean titer reached in C6/36 cells (Figure 8b). Comparatively, titers of ABV in supernatant harvested from Chao Ball cells at 7 dpi were unchanged from those detected at 2 hpi with mean titers for both time points at $10^{1.8} / \mathrm{mL}$. Similarly, only a slight, albeit significant $(p=0.017, \mathrm{t}$ test), increase in titer was detected in Mos55 cells at $7 \mathrm{dpi}$ (mean titer: $10^{2.08} / \mathrm{mL}$ ) compared to 2 hpi (mean titer: $10^{1.65} / \mathrm{mL}$ ) (Figure $8 \mathrm{~b}$ ). To investigate the unique fluorescence pattern observed in Figure 8a, ABV-infected Chao Ball, Mos55 and C6/36 cells were fixed in 100\% acetone or formaldehyde fixative buffer and immunolabeled for dsRNA. Under formaldehyde-fixed conditions, it was found that the punctate signal in Chao Ball and Mos55 cells was emphasized, whilst fixation with acetone resulted in a more diffuse cytoplasmic signal (Figure 8c). Finally, immunolabeling with ABV-specific mAbs suggested that both VP2 and VP3 were produced in ABV-infected Chao Ball and Mos55 cells, suggesting that some viral replication occurs in these cell lines (Figure 8d). 
(a)

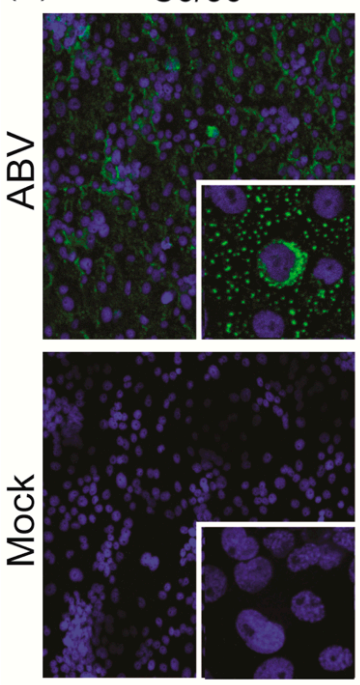

(b)

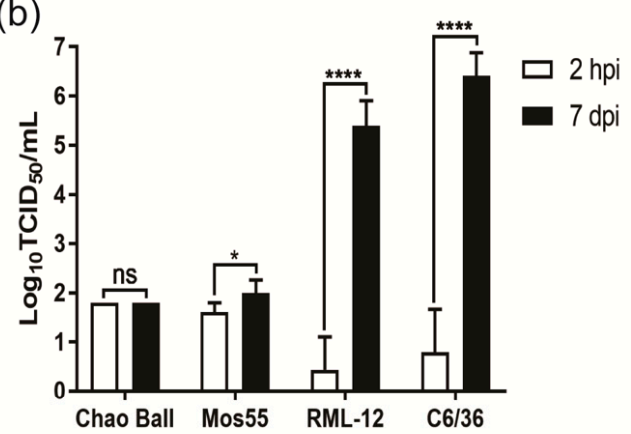

(d) Anti-VP3
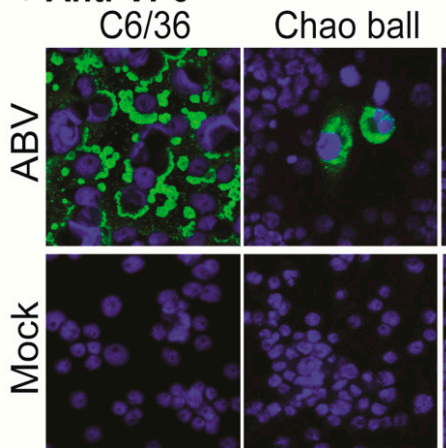

RML-12
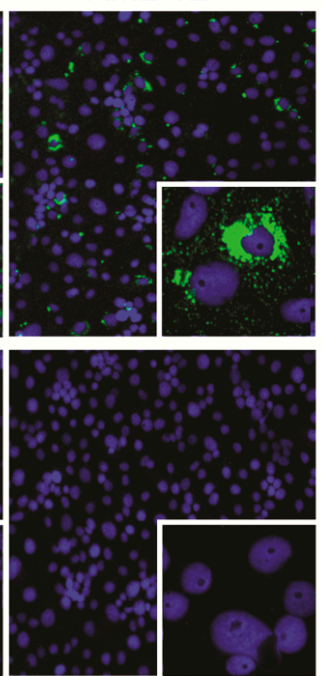

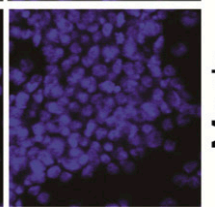

Chao ball
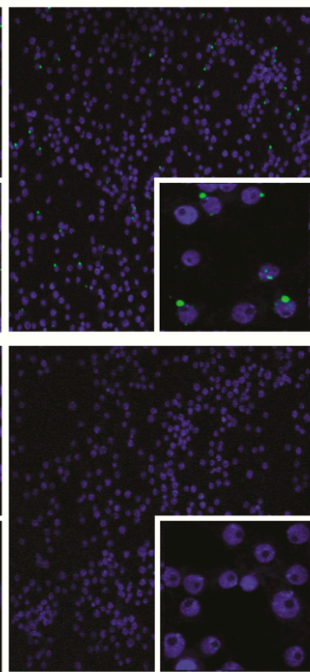

(c) $\quad \mathrm{C} 6 / 36$
Mos55
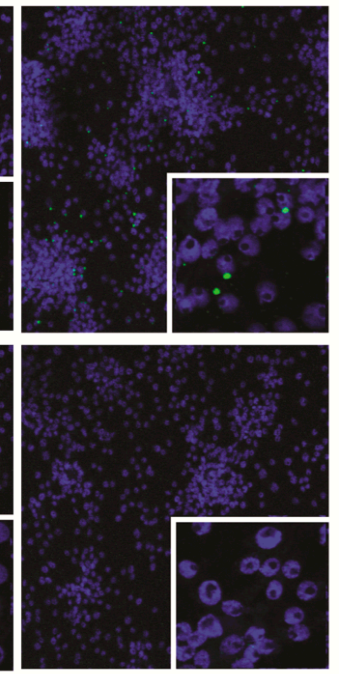

$\operatorname{Mos} 55$

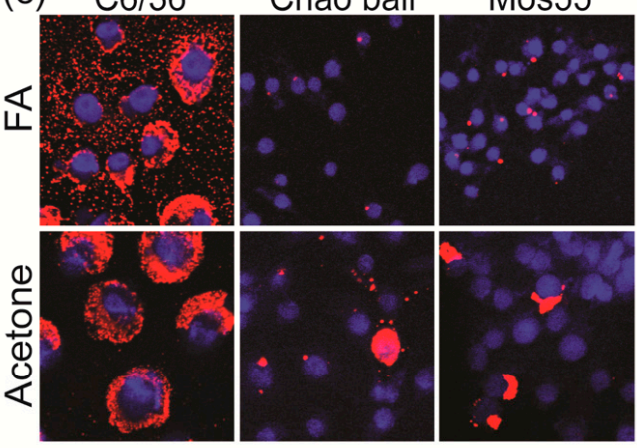

Anti-VP2
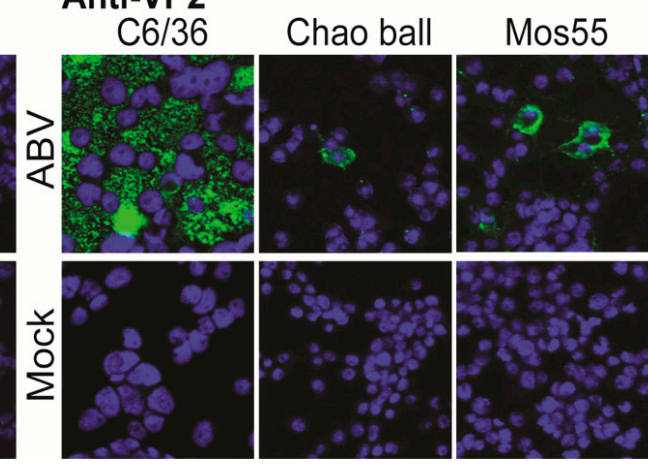

Figure 8. ABV replication in mosquito cell lines. (a) IFA performed on mosquito cells infected with ABV or mock infected (media only) fixed with $4 \%$ formaldehyde (FA) and $0.5 \%$ Triton X-100 at 7 dpi and immunolabeled for dsRNA (green) and nuclei (blue). Main panel images taken at 40x and inset at $63 x$ magnifications. (b) Mean titers in supernatants harvested from mosquito cells at 2 hpi (white) and 7 dpi (black). Error bars represent standard deviations between three replicates. Statistical significance was calculated by $\mathrm{t}$ tests using the Holm-Sidak method, with alpha $=0.05$. Each row was analyzed individually, without assuming a consistent SD. ${ }^{* * *}, p<0.0001 ;{ }^{*}, p<0.05$; ns, not significant. (c) Localization of dsRNA (red) in ABV-infected mosquito cells fixed with either $100 \%$ acetone, or $4 \%$ formaldehyde $+0.5 \%$ Triton X-100. DsRNA (red); nuclei (blue). Images taken at $63 x$ magnification. (d) ABV or mock-infected mosquito cells stained with VP3- and VP2-specific mAbs. ABV protein (green); nuclei (blue). Images taken at 40x magnification. C6/36, RNAi-deficient Ae. albopictus; RML-12, RNAi-competent Ae. albopictus; Chao Ball, Culex tarsalis; Mos55, Anopheles gambiae. 


\section{Discussion}

In this study, we describe the first isolation and characterization of a unique birnavirus from Australian mosquitoes. This virus was tentatively named Aedes birnavirus (ABV) after the Ae. notoscriptus mosquito from which it was isolated. Phylogenetic analyses indicate that ABV is not likely to be a member of the Entomobirnavirus genus. Instead, ABV forms a clade with Rotifer birnavirus (RBV), an unassigned member of the Birnaviridae that infects the microscopic aquatic animal B. plicatilis [4]. ABV was identified from a subset of mosquito pools collected in NSW, Australia, which were found to be positive for long (> $30 \mathrm{bp}$ ) double-stranded RNA (dsRNA) in fixed-cell ELISA using the MAVRIC system [26]. While many ISVs are reported as co-isolations [27,28,30], RT-PCR screening and deep sequencing performed on supernatant from the two mosquito pools containing ABV did not indicate the presence of any other virus species. A total of 77 MAVRIC-positive mosquito pools were tested for ABV, but no further isolates have been identified. It should be noted that retrospective screening in this study focused primarily on Aedes mosquito pools from Western Australia and the Northern Territory and excluded pools already known to contain other ISVs. In future studies it would be of interest to screen mosquito pools from NSW and south-east Queensland to account for a narrow geographic range which has been reported for some ISVs $[30,33,43]$. Purification of ABV by $\mathrm{CsCl}$ gradient yielded virions of icosahedral appearance with approximate diameters of $64-70 \mathrm{~nm}$, within the reported range for other birnaviruses $(55-70 \mathrm{~nm})[15,16,20]$. SDS-PAGE and mass spectrometry analysis of these particles confirmed the presence of VP1, VP3, VP4, and the small structural peptides, consistent with reports for other birnaviruses [16,39]. While bioinformatic analyses predicted the mature VP2 protein to be approximately $47.2 \mathrm{kDa}$ in size, VP2 peptides could only be detected in bands in SDS-PAGE between 70 and $150 \mathrm{kDa}$. Analysis of the polyprotein sequence of ABV revealed two unique insertions between the pVP2 and VP4 genes which are likely to be incorporated in the C-terminus of pVP2. The presence of these inserted sequences in the ABV virion was confirmed by detection of peptides mapping to these regions by mass spectrometry. With these insertions, the resulting $\mathrm{pVP} 2$ protein has an estimated molecular weight of $72.6 \mathrm{kDa}$, consistent with the size at which this protein was detected in our analyses. Thus, it appears that these purified virions predominantly contain the precursor form of the capsid protein. Studies on infectious pancreatic necrosis virus (IPNV) and infectious bursal disease virus (IBDV) have provided a model for birnavirus virion assembly and maturation. In this model, the immature or "provirion" predominantly contains pVP2 and has a diameter which is slightly larger than the mature form $[15,44]$. In the case of IPNV, immature virions were isolated by lysis of infected cells, while mature particles were isolated from cell supernatant [15]. Maturation of the virion occurs via successive cleavages at the c-terminal end of pVP2 resulting in the mature form of VP2 and 3-4 C-terminal-derived peptides which remain associated with the virion [3]. Our data suggests that particles recovered from ABV infected cells contain both pVP2 and a number of small peptides which may be derived from the C-terminus of $\mathrm{pVP} 2$. At this stage we are unable to confirm whether these particles represent the immature or mature form of ABV. However, we have shown that these particles are infectious and as ABV does not cause overt cytopathic effect, it appears that this virion form is released from infected cells via a non-lytic pathway.

Our mass spectrometry analyses suggested that ABV proteins, particularly pVP2, are suboptimally cleaved by trypsin even when preceded by Glu-C digestion. Limited information appears to be available on the protease resistance of other birnaviruses, but both trypsin and Lys-C digestion have been used for mass spectrometry analysis of birnavirus proteins by others [16,44].

In this study, we report the first production of immune sera and $\mathrm{mAbs}$ to a birnavirus isolated from mosquitoes. Analysis of these antibodies by Western blot suggested that VP3 is the immunodominant protein. However, both the immune sera and two mAbs, which did not react in Western blot, showed neutralizing activity against the virus, indicating that the predominant VP2 antibody response was to conformational or SDS-sensitive epitopes of the protein, consistent with reports for IPNV and IBDV $[45,46]$. 
No evidence of ABV replication was detected in an extensive panel of vertebrate cell lines, suggesting that the virus may possess an insect-specific phenotype similar to what has been reported for the entomobirnaviruses $[16,17,20]$. However, considering the relatedness of this virus to RBV, and the presence of aquabirnaviruses in Australia [47], it would be of interest to investigate the potential of cell lines derived from fish and other aquatic species to support ABV replication.

Intriguingly, Thirlmere virus, a birna-like virus for which no sequence data is currently available has been isolated from lake water [48]. This virus was found to be antigenically related to Drosophila $\mathrm{X}$ virus and replicated in $D$. melanogaster cells, suggesting that a birnavirus of diptera may be present in aquatic environments [48].

While ABV was able to infect and replicate to similar titers in two cell lines derived from $A e$. albopictus mosquitoes, only limited replication was observed in Mos55 (An. gambiae) and Chao Ball ( $C x$. tarsalis) cells. Under formaldehyde-fixed conditions, ABV-infected Mos55 and Chao Ball cells were characterized by a single punctate focus of dsRNA staining that contrasted with the diffuse-cytoplasmic immunostaining observed in Aedes-derived cell lines. However, when cells were fixed in acetone, dsRNA immunostaining became more diffuse, suggesting that the localization of staining may be influenced by the type of fixative used. A recent paper has demonstrated that use of alcohol and formalin-based fixatives can have a dramatic effect on the cellular localization of proteins [49].

Our in vitro data may indicate an Aedes-specific tropism for ABV, as has been described for another Australian ISV, Parramatta River virus [30]. This result is particularly interesting since Mosquito X virus (MXV) and Culex Y virus (CYV), two highly genetically similar entomobirnaviruses, were detected in mosquitoes of different genera (MXV in An. sinensis; CYV in Cx. pipiens) $[17,18]$. Furthermore, CYV infection has been reported in various cell lines derived from Culex, Aedes and Drosophila origins [50,51]

Our characterization of ABV suggests that it is a unique member of the Birnaviridae family. To our knowledge, we also report the first panel of mAbs raised to a birnavirus derived from mosquitoes. These $\mathrm{mAbs}$ will assist in future studies on the ecological niche of this virus and its relatedness to other members of the Birnaviridae. The discovery of ABV further adds to our knowledge of the virome of mosquitoes within Australia.

Supplementary Materials: The following are available online at http://www.mdpi.com/1999-4915/12/9/1056/s1, Table S1: ISV-specific primers used in this study. Figure S1. Map of mosquito collection sites and summary of additional mosquito pools screened for ABV. Figure S2. Alignment of ABV VP1 with selected birnaviruses. Figure S3. Supernatant titrations and MAVRIC IFA on vertebrate cells inoculated with ABV. File S1: Peptides identified by mass spectrometry of gel slices; excel file. File S2: Data for digestion of ABV polyprotein with trypsin or chymotrypsin; excel file. Files S3 and S4: Results of glycopeptide analysis.

Author Contributions: Conceptualization, C.A.O., H.B.-O., B.L.S., N.D.N., J.H.-P. and R.A.H.; data curation, C.A.O., C.L.P., B.H., D.W. (David Warrilow), J.J.H., J.H., A.M.G.C. and S.L.D.; formal analysis, C.A.O., C.L.P., A.S.N., B.H., D.W. (David Warrilow), J.J.H., D.P. and A.M.G.C.; funding acquisition, H.B.-O., S.L.D., J.H.-P. and R.A.H.; investigation, C.A.O., C.L.P., A.S.N., B.H., D.W. (David Warrilow), J.J.H., J.H., D.P., N.D.N. and D.W. (Daniel Watterson); methodology, C.A.O., C.L.P., A.S.N., H.B.-O., B.H., D.W. (David Warrilow), J.J.H., J.H., B.L.S., D.P., A.M.G.C., N.D.N., D.W. (Daniel Watterson) and J.H-P.; project administration, C.A.O., S.L.D., J.H.-P. and R.A.H.; resources, A.S.N., H.B.-O., B.H., D.W. (David Warrilow), J.J.H., J.H., B.L.S., A.M.G.C., S.L.D., D.W. (Daniel Watterson), J.H.-P. and R.A.H.; software, A.S.N., B.H., D.W. (David Warrilow), B.L.S., D.W. (Daniel Watterson) and R.A.H.; supervision, H.B.-O., J.H.-P. and R.A.H.; validation, C.A.O., C.L.P., A.S.N., B.H., D.W. (David Warrilow), J.J.H., J.H., B.L.S., N.D.N. and D.W. (Daniel Watterson); visualization, C.A.O., C.L.P., B.H. and D.W. (Daniel Watterson); writing-original draft, C.A.O., C.L.P., H.B.-O., D.W. (David Warrilow) and R.A.H.; writing-review and editing, C.A.O., C.L.P., A.S.N., H.B.-O., B.H., D.W. (David Warrilow), J.J.H., J.H., B.L.S., D.P., A.M.G.C., N.D.N., S.L.D., D.W. (Daniel Watterson), J.H.-P. and R.A.H. All authors have read and agreed to the published version of the manuscript.

Funding: This research was funded by an Australian Research Council Discovery Project Grant (DP120103994), UQ/UWA Collaborative Grant (BRCRA), and funding initiative for mosquito management in Western Australia (FIMMWA, Western Australia Dept. of Health). C.A.O., J.J.H., and N.D.N. were recipients of an Australian Postgraduate Scholarship Award.

Acknowledgments: We thank David Williams (CSIRO, Geelong) for graciously providing the A6 and VSW cells lines along with advice on their culture. We thank Robert Tesh (UTMB) for providing the Chao Ball and HSU cell lines and Scott O'Neill (Monash University) for provision of the MOS 55 cells. We are grateful to Cheryl Johansen and the staff of the Arbovirus Surveillance and Research Laboratory at the University of Western 
Australia for collection and processing of Western Australian mosquito pools. We thank Sally Isberg, Jasmin Moran and Bridgette Primmer (Centre for Crocodile Research) and Nina Kurucz and Allan Warchot (Medical Entomology, Public Health Unit, Top End Health Service) for collecting and providing us with Darwin mosquito samples. We are grateful to the Darwin Crocodile Farm for allowing access to collect the mosquitoes. We also thank Sonja Hall-Mendelin and Michael Onn (Queensland Health) for their assistance with mosquito identification and processing. The authors acknowledge the facilities and the scientific and technical assistance of the Australian Microscopy and Microanalysis Research Facility at the Centre for Microscopy and Microanalysis, The University of Queensland. The following icons were downloaded from the Noun Project (https://thenounproject.com) and credit belongs to the respective artists: fly, Felipe Perucho (ES); mosquito, Edward Boatman (US); leech, Andy Mc (ID).

Conflicts of Interest: MAVRIC is commercially available for research purposes via Merck (3G1) and Mozzy Mabs (2G4) https://eshop.uniquest.com.au/double-stranded-rna-monoclonal-antibody-mmabs-2g4/.

\section{Appendix A}

\section{Mass Spectrometry for Glycopeptide Detection}

Purified ABV was diluted in $6 \mathrm{M}$ Guanidine- $\mathrm{HCl}, 50 \mathrm{mM}$ Tris $\mathrm{pH} \mathrm{8}$, and $10 \mathrm{mM}$ DTT to give an approximate total protein concentration of $0.1 \mathrm{mg} / \mathrm{mL}$ and incubated for $30 \mathrm{~min}$ at $30{ }^{\circ} \mathrm{C}$ with agitation. Proteins were alkylated with $25 \mathrm{mM}$ acrylamide for $1 \mathrm{~h}$ at $30^{\circ} \mathrm{C}$ before quenching with $5 \mathrm{mM}$ DTT. Precipitation was performed in a 1:1 methanol:acetone solution overnight at $-20{ }^{\circ} \mathrm{C}$. The next day, proteins were pelleted by centrifugation at 18,000 $\mathrm{rcf}$ for $10 \mathrm{~min}$ at room temperature and methanol:acetone was allowed to evaporate. The samples were then reconstituted in $50 \mathrm{mM}$ ammonium bicarbonate $(\mathrm{ABC})$ and incubated at $37{ }^{\circ} \mathrm{C}$ with agitation. Twenty $\mu \mathrm{g}$ of protein was incubated with $0.5 \mu \mathrm{g}$ trypsin at $37^{\circ} \mathrm{C}$ for $12 \mathrm{~h}$, followed by a $12 \mathrm{~h}$ incubation with $0.5 \mu \mathrm{g}$ of Glu-C in 1 $\mathrm{mM}$ PMSF at $37^{\circ} \mathrm{C}$. Side-by-side incubations with and without 250 units of PNGase F were performed on $10 \mu \mathrm{g}$ of protein at $37^{\circ} \mathrm{C}$ overnight.

Samples were dried and reconstituted in $0.1 \%$ formic acid and $250 \mathrm{ng}(5 \mu \mathrm{L})$ was injected for each chromatographic run using a Dionex UltiMate 3000 uHPLC system (Thermo Fisher Scientific, Bremen, Germany). Solvent A was $1 \% \mathrm{CH} 3 \mathrm{CN}$ in $0.1 \%(v / v)$ aqueous formic acid and solvent B was $80 \%(v / v)$ $\mathrm{CH} 3 \mathrm{CN}$ containing $0.1 \%(v / v)$ formic acid. Samples were loaded onto a C18 AcclaimTM PepMapTM trap column ( $100 \AA, 5 \mu \mathrm{m} \times 0.3 \mathrm{~mm} \times 5 \mathrm{~mm}$, Thermo Fisher Scientific) and washed for $3 \mathrm{~min}$ at $30 \mu \mathrm{L} / \mathrm{min}$ before peptides were eluted onto a Vydac Everest C18 column $(75 \mu \mathrm{m} \times 75 \mathrm{~mm}, 2 \mu \mathrm{m}, 300 \AA$, Hichrom, UK) at a flow rate of $0.3 \mu \mathrm{L} / \mathrm{min}$. Peptides were separated with a gradient of $3 \%$ to $50 \%$ solvent $B$ over $34 \mathrm{~min}$. The samples were analyzed on an Orbitrap Elite mass spectrometer (Thermo Fisher Scientific). Survey scans of peptide precursors from an $\mathrm{m} / \mathrm{z}$ of 350 to 1800 were acquired in the Orbitrap at a resolution of $120 \mathrm{~K}$ (full width at half-maximum, FWHM) at $400 \mathrm{~m} / \mathrm{z}$ using an automatic gain control target of 1,000,000 and maximum injection time of $200 \mathrm{~ms}$. The ten most-intense precursors with charge states above two were selected for fragmentation by higher-energy C-trap dissociation (HCD) using a normalized collision energy of 35\% with a precursor isolation window of $2 \mathrm{Da}$. Fragment ions were acquired in the Orbitrap at a resolution of $30 \mathrm{~K}$ using an automatic gain control target of 100,000 and maximum injection time of $200 \mathrm{~ms}$.

Byonic software (Protein Metrics, v. 2.13.17) was used to search spectra from the RAW files generated by MS analysis. The protein database used contained Aedes albopictus proteins (UniProt reference proteome UP0000069940, downloaded 02 February 2019 and NCBI entry XP_019528968), and the amino acid sequences of ABV polyprotein and RdRP with a custom contaminants database. Cleavage specificity was set as C-terminal to Arg, Lys, Asp and Glu and a maximum of four missed cleavages were allowed. Mass tolerances of 10 and 15 ppm were applied to precursor and fragment ions, respectively. Cys-S-beta-propionamide was set as a static modification, and dynamic modifications included deamidation of Asn and oxidation of Met. A database of 28 insect N-linked glycans was used for $\mathrm{N}$-linked searches. For O-linked searches, the protein database was reduced to birnavirus proteins only and the Byonic six common O-linked glycan database was used. In addition, a wildcard search was enabled, allowing -40 to $+500 \mathrm{Da}$ at all residues to accommodate any monosaccharide residues that may be specific to Aedes albopictus. Manual de novo sequencing and validation of Byonic results 
was conducted using Xcalibur Qual Browser (v. 3.0.63 Thermo Scientific). For de novo sequencing of glycopeptides, an extracted ion chromatograph for the theoretical $\mathrm{m} / \mathrm{z}$ value of [HexNAc $+\mathrm{H}]+$ (204.0867) and [Hex $+\mathrm{H}]+(163.0601)$ was used and the theoretical masses of peptide and peptide fragment ions were calculated using the MS-Digest and MS-Product modules of Protein Prospector, respectively (http://prospector.ucsf.edu).

\section{References}

1. Coulibaly, F.; Chevalier, C.; Gutsche, I.; Pous, J.; Navaza, J.; Bressanelli, S.; Delmas, B.; Rey, F.A. The Birnavirus Crystal Structure Reveals Structural Relationships among Icosahedral Viruses. Cell 2005, 120, 761-772. [CrossRef] [PubMed]

2. Gibrat, J.-F.; Mariadassou, M.; Boudinot, P.; Delmas, B. Analyses of the radiation of birnaviruses from diverse host phyla and of their evolutionary affinities with other double-stranded RNA and positive strand RNA viruses using robust structure-based multiple sequence alignments and advanced phylogenetic methods. BMC Evol. Boil. 2013, 13, 154. [CrossRef]

3. Delmas, B.; Attoui, H.; Ghosh, S.; Malik, Y.S.; Mundt, E.; Vakharia, V.N. ICTV Report Consortium ICTV virus taxonomy profile: Birnaviridae. J. Gen. Virol. 2019, 100, 5-6. [CrossRef] [PubMed]

4. Comps, M.; Mari, J.; Poisson, F.; Bonami, J.-R. Biophysical and biochemical properties of an unusual birnavirus pathogenic for rotifers. J. Gen. Virol. 1991, 72, 1229-1236. [CrossRef]

5. Wu, Q.; Luo, Y.; Lu, R.; Lau, N.C.; Lai, E.C.; Li, W.-X.; Ding, S.-W. Virus discovery by deep sequencing and assembly of virus-derived small silencing RNAs. Proc. Natl. Acad. Sci. USA 2010, 107, 1606-1611. [CrossRef]

6. Da Costa, B.; Chevalier, C.; Henry, C.; Huet, J.-C.; Petit, S.; Lepault, J.; Boot, H.; Delmas, B. The Capsid of Infectious Bursal Disease Virus Contains Several Small Peptides Arising from the Maturation Process of pVP2. J. Virol. 2002, 76, 2393-2402. [CrossRef]

7. Pan, J.; Vakharia, V.N.; Tao, Y.J. The structure of a birnavirus polymerase reveals a distinct active site topology. Proc. Natl. Acad. Sci. USA 2007, 104, 7385-7390. [CrossRef]

8. Shwed, P.S.; Dobos, P.; Cameron, L.A.; Vakharia, V.N.; Duncan, R. Birnavirus VP1 Proteins Form a Distinct Subgroup of RNA-Dependent RNA Polymerases Lacking a GDD Motif. Virol. 2002, 296, 241-250. [CrossRef]

9. Zhang, C.-X.; Suzuki, S. Comparison of the RNA polymerase genes of marine birnavirus strains and other birnaviruses. Arch. Virol. 2003, 148, 745-758. [CrossRef]

10. Giménez, M.C.; Zanetti, F.A.; Terebiznik, M.R.; Colombo, M.I.; Delgui, L.R. Infectious Bursal Disease Virus Hijacks Endosomal Membranes as the Scaffolding Structure for Viral Replication. J. Virol. 2018, 92, e01964-17. [CrossRef]

11. Delgui, L.R.; Rodríguez, J.F.; Colombo, M.I. The Endosomal Pathway and the Golgi Complex Are Involved in the Infectious Bursal Disease Virus Life Cycle. J. Virol. 2013, 87, 8993-9007. [CrossRef] [PubMed]

12. Chevalier, C.; Lepault, J.; Erk, I.; Da Costa, B.; Delmas, B. The Maturation Process of pVP2 Requires Assembly of Infectious Bursal Disease Virus Capsids. J. Virol. 2002, 76, 2384-2392. [CrossRef] [PubMed]

13. Maraver, A.; Oña, A.; Abaitua, F.; González, D.; Clemente, R.; Ruiz-Díaz, J.A.; Castón, J.R.; Pazos, F.; Rodríguez, J.F. The Oligomerization Domain of VP3, the Scaffolding Protein of Infectious Bursal Disease Virus, Plays a Critical Role in Capsid Assembly. J. Virol. 2003, 77, 6438-6449. [CrossRef] [PubMed]

14. Oña, A.; Luque, D.; Abaitua, F.; Maraver, A.; Castón, J.R.; Rodríguez, J.F. The C-terminal domain of the pVP2 precursor is essential for the interaction between VP2 and VP3, the capsid polypeptides of infectious bursal disease virus. Virology 2004, 322, 135-142. [CrossRef] [PubMed]

15. Villanueva, R.A.; Galaz, J.L.; Valdés, J.A.; Jashés, M.M.; Sandino, A.M. Genome Assembly and Particle Maturation of the Birnavirus Infectious Pancreatic Necrosis Virus. J. Virol. 2004, 78, 13829-13838. [CrossRef]

16. Vancini, R.; Paredes, A.; Ribeiro, M.; Blackburn, K.; Ferreira, D.; Kononchik, J.P.; Hernandez, R.; Brown, D.T. Espirito Santo Virus: A New Birnavirus That Replicates in Insect Cells. J. Virol. 2011, 86, 2390-2399. [CrossRef]

17. Marklewitz, M.; Gloza-Rausch, F.; Kurth, A.; Kümmerer, B.M.; Drosten, C.; Junglen, S. First isolation of an Entomobirnavirus from free-living insects. J. Gen. Virol. 2012, 93, 2431-2435. [CrossRef]

18. Huang, Y.; Mi, Z.; Zhuang, L.; Ma, M.-J.; An, X.; Liu, W.; Cao, W.; Tong, Y. Presence of entomobirnaviruses in Chinese mosquitoes in the absence of Dengue virus co-infection. J. Gen. Virol. 2013, 94, 663-667. [CrossRef] 
19. Cook, S.; Chung, B.Y.-W.; Bass, D.; Moureau, G.; Tang, S.; McAlister, E.; Culverwell, C.L.; Glücksman, E.; Wang, H.; Brown, T.D.K.; et al. Novel Virus Discovery and Genome Reconstruction from Field RNA Samples Reveals Highly Divergent Viruses in Dipteran Hosts. PLoS ONE 2013, 8, e80720. [CrossRef]

20. Tesh, R.B.; Bolling, B.G.; Guzman, H.; Popov, V.L.; Wilson, A.; Widen, S.G.; Wood, T.G.; Walker, P.J.; Vasilakis, N. Characterization of Port Bolivar Virus, a Novel Entomobirnavirus (Birnaviridae) Isolated from Mosquitoes Collected in East Texas, USA. Viruses 2020, 12, 390. [CrossRef]

21. Hall, R.A.; Bielefeldt-Ohmann, H.; McLean, B.J.; O’Brien, C.A.; Colmant, A.M.; Piyasena, T.B.; Harrison, J.J.; Newton, N.D.; Barnard, R.T.; Prow, N.A.; et al. Commensal Viruses of Mosquitoes: Host Restriction, Transmission, and Interaction with Arboviral Pathogens. Evol. Bioinform. 2017, 12, 35-44. [CrossRef]

22. Piyasena, T.B.H.; Newton, N.D.; Hobson-Peters, J.; Vet, L.J.; Setoh, Y.X.; Bielefeldt-Ohmann, H.; Khromykh, A.A.; Hall, R.A. Chimeric viruses of the insect-specific flavivirus Palm Creek with structural proteins of vertebrate-infecting flaviviruses identify barriers to replication of insect-specific flaviviruses in vertebrate cells. J. Gen. Virol. 2019, 100, 1580-1586. [CrossRef]

23. Hall-Mendelin, S.; McLean, B.J.; Bielefeldt-Ohmann, H.; Hobson-Peters, J.; Hall, R.A.; Hurk, A.F.V.D. The insect-specific Palm Creek virus modulates West Nile virus infection in and transmission by Australian mosquitoes. Parasites Vectors 2016, 9, 414. [CrossRef] [PubMed]

24. Erasmus, J.H.; Seymour, R.L.; Kaelber, J.T.; Kim, D.Y.; Leal, G.; Sherman, M.B.; Frolov, I.; Chiu, W.; Weaver, S.C.; Nasar, F. Novel insect-specific Eilat virus-based chimeric vaccine candidates provide durable, mono- and multi-valent, single dose protection against lethal alphavirus challenge. J. Virol. 2017, 92, e01274-17. [CrossRef] [PubMed]

25. Hobson-Peters, J.; Harrison, J.J.; Watterson, D.; Hazlewood, J.E.; Vet, L.J.; Newton, N.D.; Warrilow, D.; Colmant, A.M.; Taylor, C.; Huang, B.; et al. A recombinant platform for flavivirus vaccines and diagnostics using chimeras of a new insect-specific virus. Sci. Transl. Med. 2019, 11, eaax7888. [CrossRef]

26. O’Brien, C.A.; Hobson-Peters, J.; Yam, A.W.Y.; Colmant, A.M.; McLean, B.J.; Prow, N.A.; Watterson, D.; Hall-Mendelin, S.; Warrilow, D.; Ng, M.-L.; et al. Viral RNA Intermediates as Targets for Detection and Discovery of Novel and Emerging Mosquito-Borne Viruses. PLOS Neglected Trop. Dis. 2015, 9, e0003629. [CrossRef] [PubMed]

27. A O'Brien, C.; McLean, B.J.; Colmant, A.M.; Harrison, J.J.; Hall-Mendelin, S.; Hurk, A.F.V.D.; A Johansen, C.; Watterson, D.; Bielefeldt-Ohmann, H.; Newton, N.D.; et al. Discovery and Characterisation of Castlerea Virus, a New Species ofNegevirusIsolated in Australia. Evol. Bioinform. 2017, 13, 1176934317691269. [CrossRef] [PubMed]

28. Prow, N.A.; Mah, M.G.; Deerain, J.M.; Warrilow, D.; Colmant, A.M.; O’Brien, C.A.; Harrison, J.J.; McLean, B.J.; Hewlett, E.K.; Piyasena, T.B.H.; et al. New genotypes of Liao ning virus (LNV) in Australia exhibit an insect-specific phenotype. J. Gen. Virol. 2018, 99, 596-609. [CrossRef]

29. Harrison, J.J.; Warrilow, D.; McLean, B.J.; Watterson, D.; O’Brien, C.A.; Colmant, A.M.; Johansen, C.A.; Barnard, R.T.; Hall-Mendelin, S.; Davis, S.S.; et al. A New Orbivirus Isolated from Mosquitoes in North-Western Australia Shows Antigenic and Genetic Similarity to Corriparta Virus but Does Not Replicate in Vertebrate Cells. Viruses 2016, 8, 141. [CrossRef]

30. McLean, B.J.; Hobson-Peters, J.; Webb, C.E.; Watterson, D.; Prow, N.A.; Nguyen, H.D.; Hall-Mendelin, S.; Warrilow, D.; Johansen, C.A.; Jansen, C.C.; et al. A novel insect-specific flavivirus replicates only in Aedes-derived cells and persists at high prevalence in wild Aedes vigilax populations in Sydney, Australia. Virology 2015, 486, 272-283. [CrossRef]

31. Warrilow, D.; Huang, B.; Newton, N.D.; Harrison, J.J.; Johnson, K.N.; Chow, W.K.; Hall, R.A.; Hobson-Peters, J. The taxonomy of an Australian nodavirus isolated from mosquitoes. PLoS ONE 2018, 13, e0210029. [CrossRef] [PubMed]

32. Colmant, A.M.; O’Brien, C.A.; Newton, N.D.; Watterson, D.; Hardy, J.M.; Coulibaly, F.; Bielefeldt-Ohmann, H.; Warrilow, D.; Huang, B.; Paramitha, D.; et al. Novel monoclonal antibodies against Australian strains of negeviruses and insights into virus structure, replication and host -restriction. J. Gen. Virol. 2020, 101, 440-452. [CrossRef] [PubMed]

33. Warrilow, D.; Watterson, D.; Hall, R.A.; Davis, S.S.; Weir, R.; Kurucz, N.; Whelan, P.; Allcock, R.; Hall-Mendelin, S.; O’Brien, C.A.; et al. A New Species of Mesonivirus from the Northern Territory, Australia. PLoS ONE 2014, 9, e91103. [CrossRef] [PubMed] 
34. Hobson-Peters, J.; Yam, A.W.Y.; Lu, J.; Setoh, Y.X.; May, F.; Kurucz, N.; Walsh, S.; Prow, N.A.; Davis, S.S.; Weir, R.; et al. A New Insect-Specific Flavivirus from Northern Australia Suppresses Replication of West Nile Virus and Murray Valley Encephalitis Virus in Co-infected Mosquito Cells. PLoS ONE 2013, 8, e56534. [CrossRef] [PubMed]

35. Miller, M.; Pfeiffer, W.; Schwartz, T. Creating the CIPRES Science Gateway for inference of large phylogenetic trees. In Proceedings of the Gateway Computing Environments Workshop (GCE), New Orleans, LA, USA, 14 November 2010; pp. 1-8.

36. Reed, L.J.; Muench, H. A simple method of estimating fifty percent endpoints. Am J Epidemiol 1938, 27, 493-497. [CrossRef]

37. Goh, L.Y.; Hobson-Peters, J.; Prow, N.A.; Gardner, J.; Bielefeldt-Ohmann, H.; Pyke, A.T.; Suhrbier, A.; Hall, R.A. Neutralizing monoclonal antibodies to the E2 protein of chikungunya virus protects against disease in a mouse model. Clin. Immunol. 2013, 149, 487-497. [CrossRef] [PubMed]

38. Irigoyen, N.; Garriga, D.; Navarro, A.; Verdaguer, N.; Rodríguez, J.F.; Castón, J.R. Autoproteolytic Activity Derived from the Infectious Bursal Disease Virus Capsid Protein. J. Boil. Chem. 2009, 284, 8064-8072. [CrossRef]

39. Dobos, P. The molecular biology of infectious pancreatic necrosis virus (IPNV). Annu. Rev. Fish Dis. 1995, 5, 25-54. [CrossRef]

40. Giansanti, P.; Tsiatsiani, L.; Low, T.Y.; Heck, A.J.R. Six alternative proteases for mass spectrometry-based proteomics beyond trypsin. Nat. Protoc. 2016, 11, 993-1006. [CrossRef]

41. Imajoh, M.; Goto, T.; Oshima, S. Characterization of cleavage sites and protease activity in the polyprotein precursor of Japanese marine aquabirnavirus and expression analysis of generated proteins by a VP4 protease activity in four distinct cell lines. Arch. Virol. 2007, 152, 1103-1114. [CrossRef]

42. Petit, S.; Lejal, N.; Huet, J.-C.; Delmas, B. Active Residues and Viral Substrate Cleavage Sites of the Protease of the Birnavirus Infectious Pancreatic Necrosis Virus. J. Virol. 2000, 74, 2057-2066. [CrossRef] [PubMed]

43. Hobson-Peters, J.; Warrilow, D.; McLean, B.J.; Watterson, D.; Colmant, A.M.; Hurk, A.F.V.D.; Hall-Mendelin, S.; Hastie, M.L.; Gorman, J.J.; Harrison, J.J.; et al. Discovery and characterisation of a new insect-specific bunyavirus from Culex mosquitoes captured in northern Australia. Virology 2016, 489, 269-281. [CrossRef]

44. Pous, J.; Chevalier, C.; Ouldali, M.; Navaza, J.; Delmas, B.; Lepault, J. Structure of birnavirus-like particles determined by combined electron cryomicroscopy and X-ray crystallography. J. Gen. Virol. 2005, 86, 2339-2346. [CrossRef] [PubMed]

45. Frost, P.; Havarstein, L.S.; Lygren, B.; Ståhl, S.; Endresen, C.; Christie, K.E. Mapping of neutralization epitopes on infectious pancreatic necrosis viruses. J. Gen. Virol. 1995, 76, 1165-1172. [CrossRef]

46. Fahey, K.J.; Erny, K.; Crooks, J. A Conformational Immunogen on VP-2 of Infectious Bursal Disease Virus that Induces Virus-neutralizing Antibodies that Passively Protect Chickens. J. Gen. Virol. 1989, 70, 1473-1481. [CrossRef] [PubMed]

47. McCowan, C.; Motha, J.; Crane, M.; Moody, N.; Crameri, S.; Hyatt, A.; Bradley, T. Isolation of a novel aquatic birnavirus from rainbow trout Oncorhynchus mykiss in Australia. Dis. Aquat. Org. 2015, 114, 117-125. [CrossRef] [PubMed]

48. Kelly, D.C.; Ayres, M.D.; Howard, S.C.; Lescott, T.; Arnold, M.K.; Seeley, N.D.; Primrose, S.B. Isolation of a Bisegmented Double-stranded RNA Virus from Thirlmere Reservoir. J. Gen. Virol. 1982, 62, 313-322. [CrossRef]

49. Banerjee, A.; Falzarano, D.; Misra, V. Caution: Choice of fixative can influence the visualization of the location of a transcription factor in mammalian cells. BioTechniques 2018, 65, 65-69. [CrossRef]

50. Van Cleef, K.W.; Van Mierlo, J.T.; Miesen, P.; Overheul, G.J.; Fros, J.J.; Schuster, S.; Marklewitz, M.; Pijlman, G.; Junglen, S.; Van Rij, R.P. Mosquito and Drosophila entomobirnaviruses suppress dsRNA- and siRNA-induced RNAi. Nucleic Acids Res. 2014, 42, 8732-8744. [CrossRef]

51. Franzke, K.; Leggewie, M.; Sreenu, V.B.; Jansen, S.; Heitmann, A.; Welch, S.R.; Brennan, B.; Elliott, R.M.; Tannich, E.; Becker, S.C.; et al. Detection, infection dynamics and small RNA response against Culex $Y$ virus in mosquiot-derived cells. J. Gen. Virol. 2018, 99, 1739-1745. [CrossRef]

(C) 2020 by the authors. Licensee MDPI, Basel, Switzerland. This article is an open access article distributed under the terms and conditions of the Creative Commons Attribution (CC BY) license (http://creativecommons.org/licenses/by/4.0/). 